جامعتمالموصل

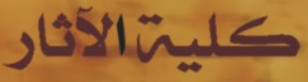

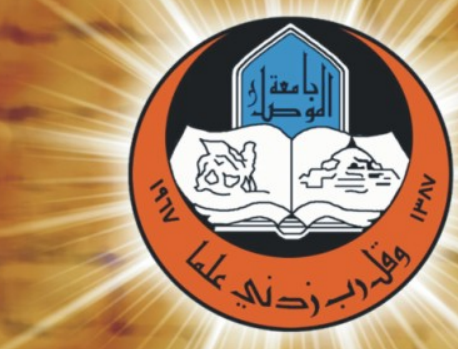

$$
\begin{aligned}
& \text { وزارة التعليمالعالي } \\
& \text { والبحث العلمي }
\end{aligned}
$$

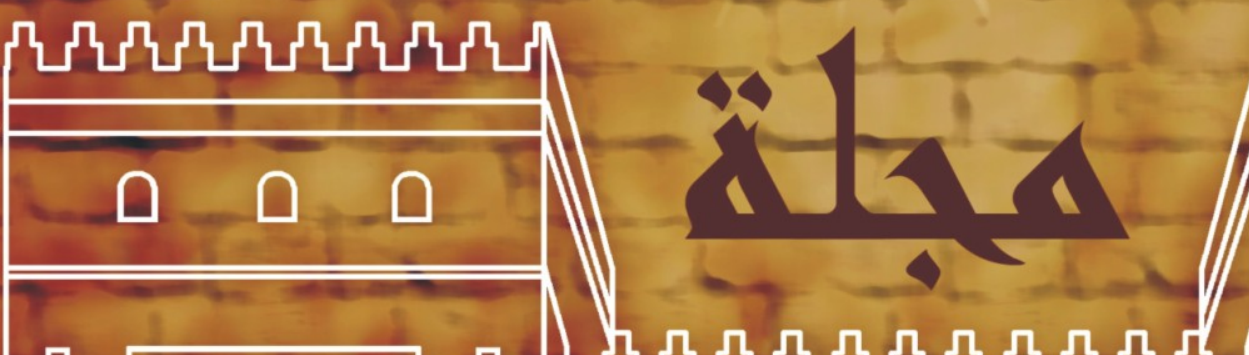

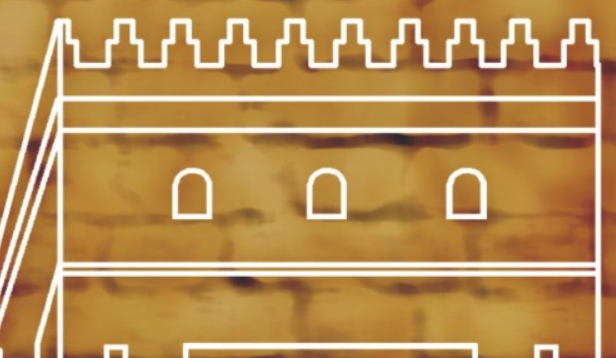

(3)

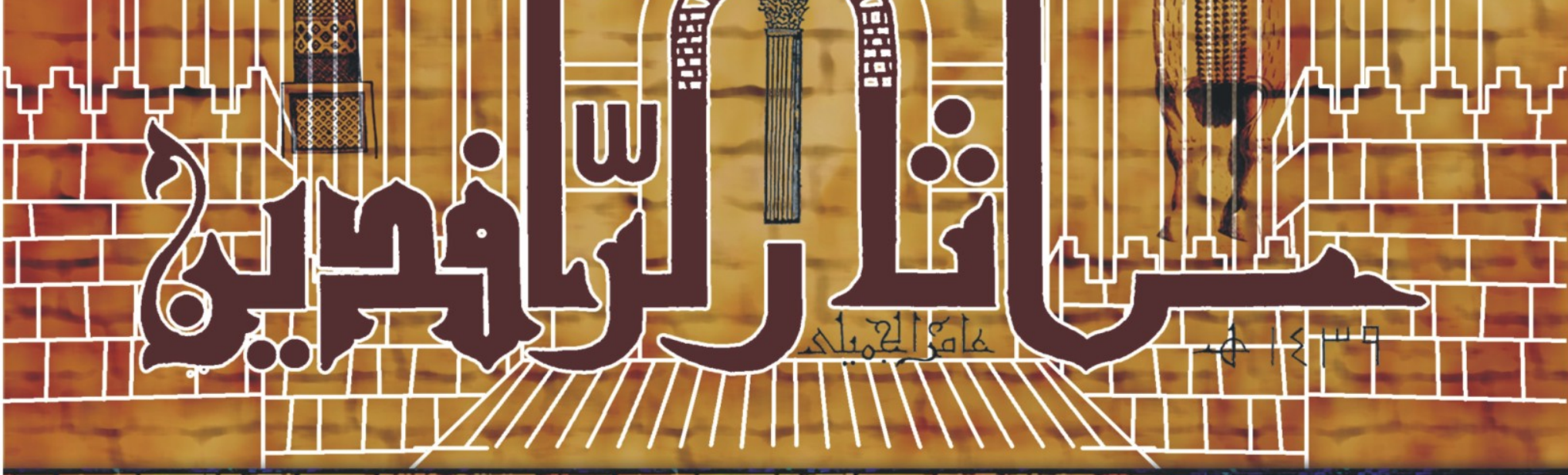

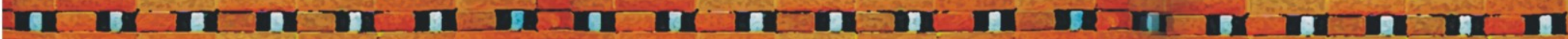

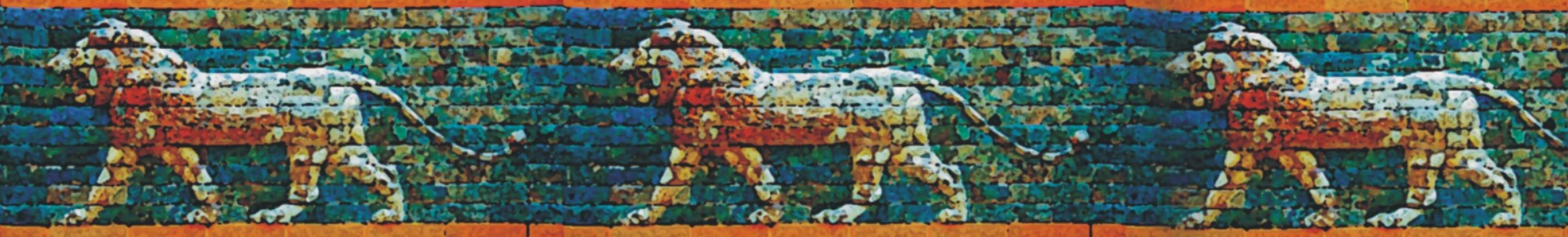

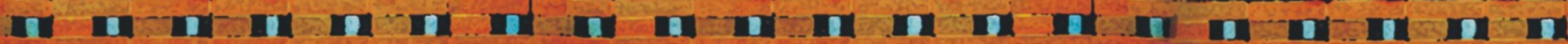

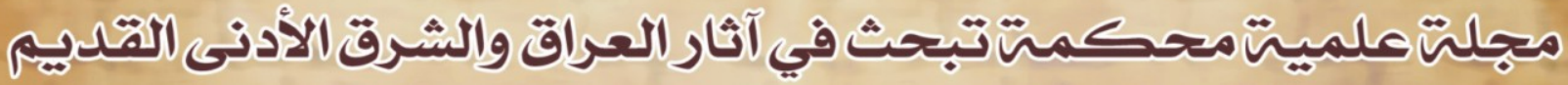

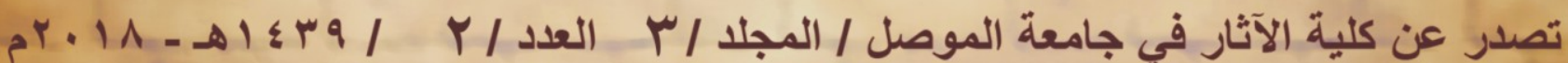




رقم الإِيداع في دار الكتب و الوثائق ببذداد

relr (IVIr) (لسنة 



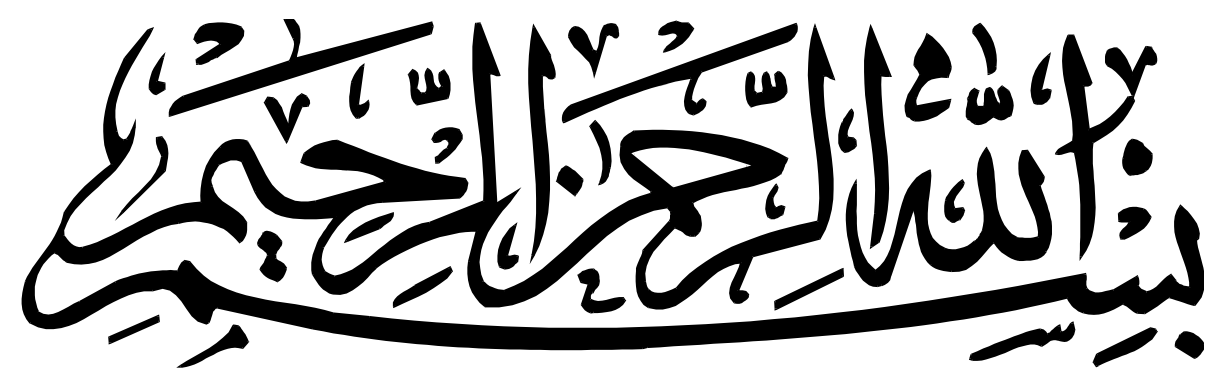





$$
\text { أ.د. علي ياسة التمرير الجبوري }
$$

أ.م.د. فيسان هوفق رشيد النعيشي سكرتير التصرير
أ.د. صفوان ساهي سعيد الرفاعي نائب رئيس التمرير

الألعناs

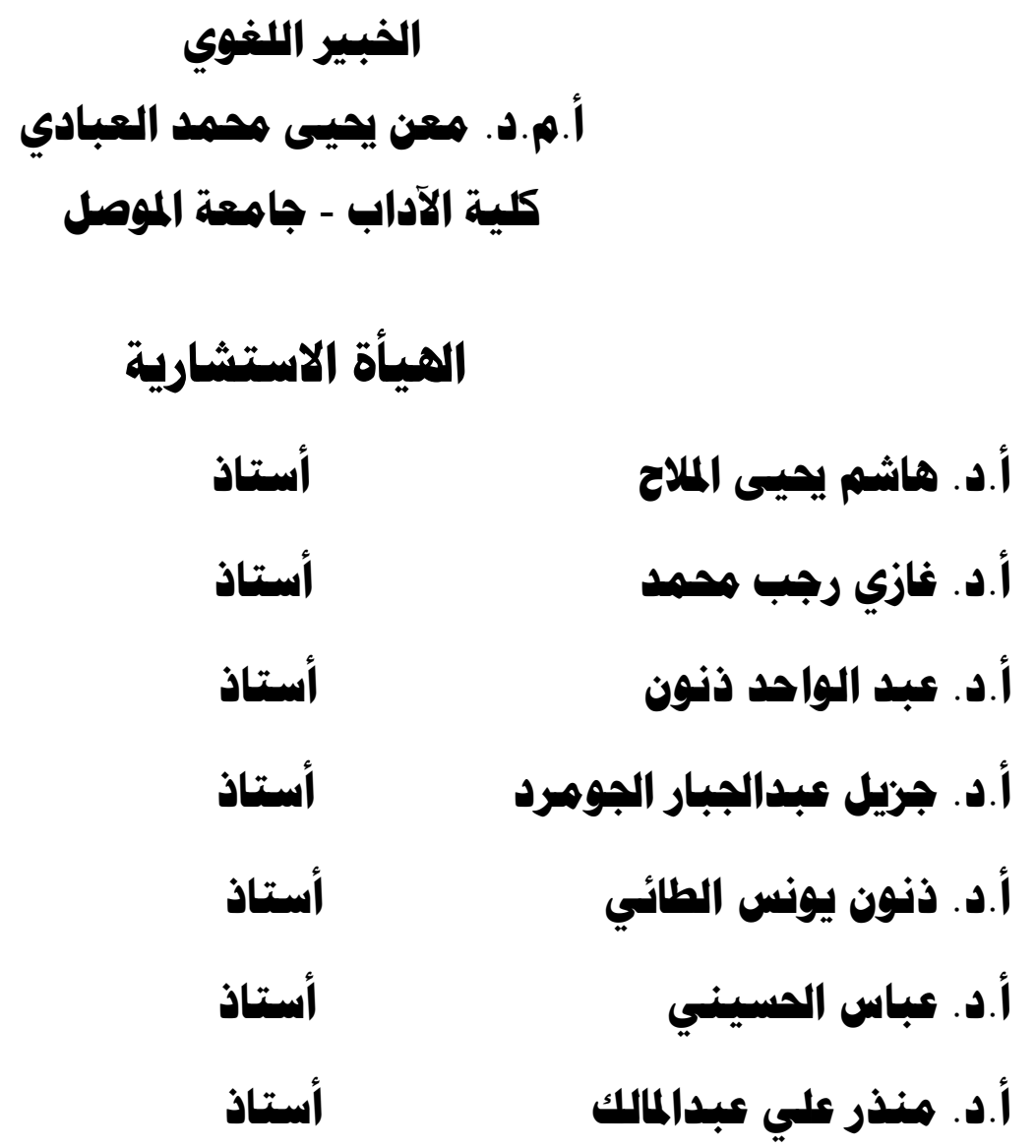

جاهمة الموصل

جاهمة بغداد

جامعة الموصل

جاهعة الموصل

جاهمة الموصل

جاهعة القادسية

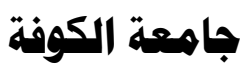

\author{
أ.د. شعلان كاهل اسماويل \\ أ.د. عاهر عبدالله نجم الجُميلي \\ أ.م.د. زهير ضياء الدين سعيد الرفاعي

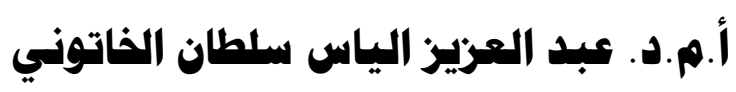





\section{قواعد النشر في المبلة}

• يشترط أن يكون البحث ضهن الاختصاصات التي تُعنى بها المجلة • يشترط على الباحث الالتزام بالموضوعية و المنهج العلمي في البحث و التحليل ،و أن يلتزه بشروط البحث العلمي هن حيث التبويب و استعمال الهواهش و الإشارة إلى المصادر و المراجع وفق طريقة هنهجية و احدة ،و في

$$
\text { آخر البحث }
$$

• يشترط على الباحث هراعاة الجوانب الشكلية و الاهتهام بسلاهة لغة البحث هن الأخطاء اللغوية و المطبعية

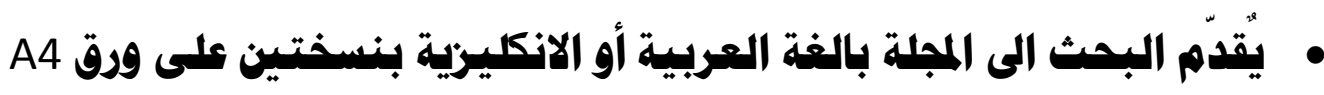
• يرافق البحث في أوله هلخص" باللغة الانكليزية على أن لا يريد عدد كلماته

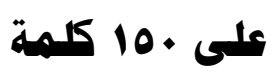

• يشترط أن لا يكون البحث قد نشر او قبل للنشر في أيّة دورية علمية داخل

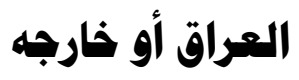

• يشترط على الباحث أن لا تتجاوز عدد صفحات بثثه عن ro صفحة • يشترط في البحث أن تكون المشاهد و الأشكال الفنية المرافقة له عالية الجودة • أصول البحث المقدهة إلى البلة لا ترد أو تُسترجع سواء نشرت أم لم تنشر • تعتمد المجلة هبدأ التمويل الذاتي وتهدد أجور النشر في ضوء الأسعار السائدة 



\section{ثبت المتويات}

\begin{tabular}{|c|c|c|}
\hline 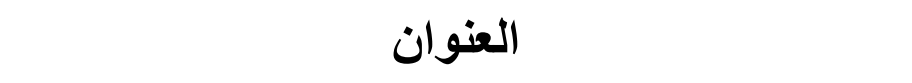 & اسم الباحث & الصفحة \\
\hline تؤُطئة & أبد. علي ياسين الجبوري & $r_{-1}$ \\
\hline قر اءة النص المسماري وتحليله ( تحقيقه ) & 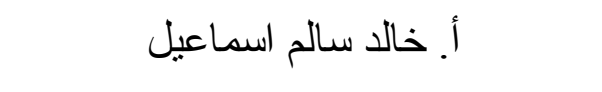 & $r \cdot-r$ \\
\hline آداب تتاول الطعام و الثر اب عند المصريين القدماء & أ.د.حسين ظاهر حمود & $\left\{\tau_{-},{ }_{1}\right.$ \\
\hline دمن ومو القع جغر افية نسبت لأسماء النباتات في ضو اء المسارية & أ. أ. د. د. دؤيد محمد سليمان الدلّيمي & $\Lambda_{-} \leqslant \vee$ \\
\hline مشاعر الأنسان و انعكاسها في الخطاب الرسميّ في المملكة & أد. ي. صفو هان سامي سعيد & $\mid r \varepsilon_{-} \wedge 9$ \\
\hline 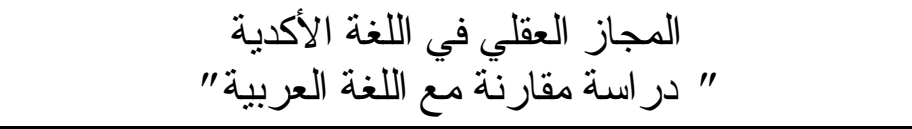 & أ.م.د. ز هير ضياء الدين سعيد الرفاعي & $1 \leqslant \cdot-1 r_{0}$ \\
\hline أثنز البيئة في اقتصاد بلاد الر افدين إبان عصور ما قبل & أ.م.د. حسين يوسف حازم & $17 \cdot-1 \leqslant 1$ \\
\hline حقوق الجار المتضرر في القانون العر اقي القديم & أ. م. د عبدالرحمن يونس عبدالرحمن & $\left|V \Lambda_{-}\right| 7 \mid$ \\
\hline الأسطورة بوصفها مصدر الدر اسة التاريخ أسطورة قايين & أ. م.د. محمد العلامي & $117_{-} 1 \mathrm{~V}$ \\
\hline الخصائص المعمارية المشتركة في تخطيط البيمارستان العبان & أ.ج.د. اكرم محمد يحيى & $r Y \leq-1 \wedge V$ \\
\hline دار غز الة في حي الجديدة بمدينة حلب في العهد العثمانيز & د. محمد خضر محمود & $r \leqslant \varepsilon-r Y_{0}$ \\
\hline 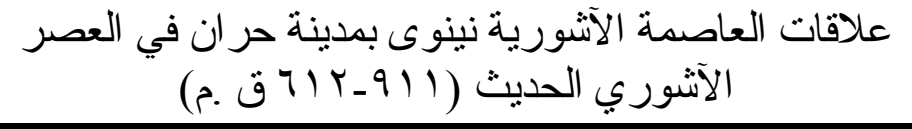 & د. إيمان هاني العلوش & rON-Y $\leq 0$ \\
\hline الابن البار و الابن العاق في المجتمع البابلي & د. هبة حازم محمد النعيمي & $r V \varepsilon-Y \circ 9$ \\
\hline 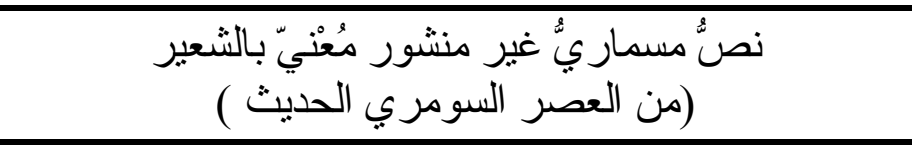 & د د معاذ حبش خضر & YQY_rVO \\
\hline عبار ات التهديد في رسائل العصر البابليّ القديم & د. د. رامي عبد الحكيم قاسم العبادي & $r \cdot t_{-1}+T^{2}$ \\
\hline
\end{tabular}





\begin{tabular}{|c|c|c|}
\hline عقود إيجار غير منشورة من عهد الملك البابلي سمسو-إيلونا & د. ياسر جابر خليل & V. \\
\hline 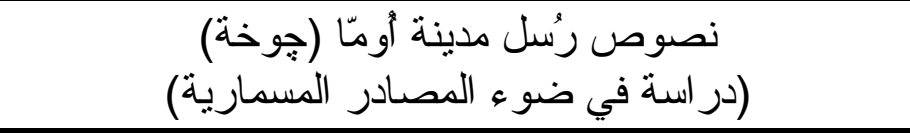 & د. أباذر ر اهي سعدون الزيدي & וسד__ט \\
\hline صياغة عقود الدين في العصر البابليّ القديم & م. أحمد ميسر فاضل & $r v \varepsilon_{-} r \Delta 0$ \\
\hline الحفاظ على المباني الأثرية المشيدة بالحجارة من العو امل & م: رنا وعد الله مهدي & rqr_rvo \\
\hline الصائغ وحرفته في العر اق القديم في ضوء المسمادر & م.م .ر عد سالم محمد المعماري & سqu_s \\
\hline
\end{tabular}

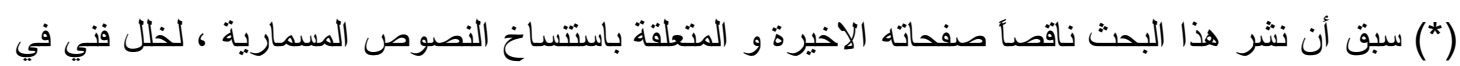

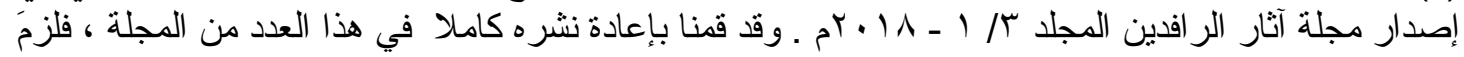





\section{توطئة}

أ.د. علي ياسين الجبوري

\section{رئيس هيأة التحرير}

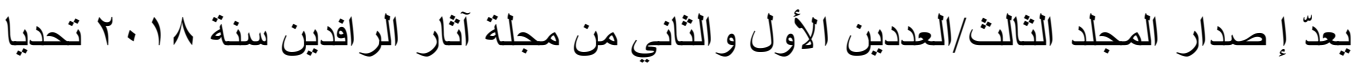

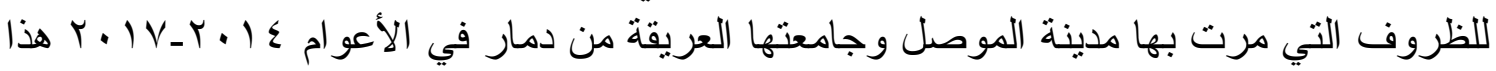

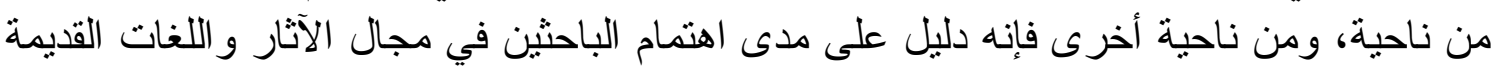
وتقتهم بمجلة آثار الر افدين

تهتم المجلة بجميع الأبحاث التي تعالج مو اضيع ذات علاقة بالمبن المعارف التاريخية و السياسية و الحضارية لبلاد الر افدين و الثرق الأدنى القديم وللعصور القديمة و الإسلامية كافة التهاف

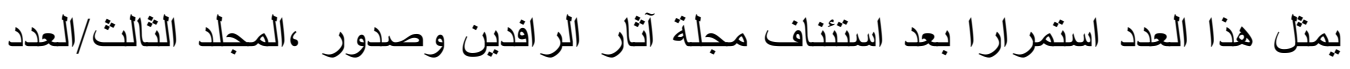

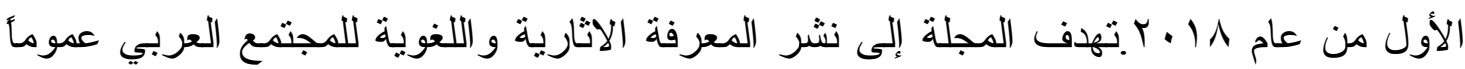

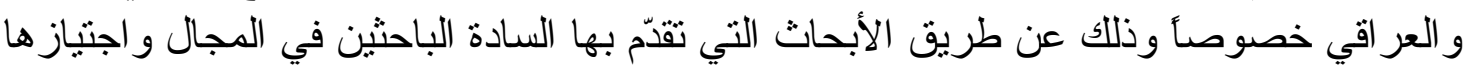

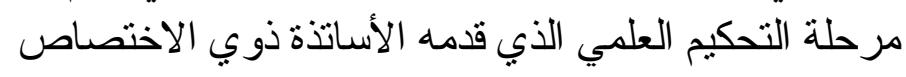

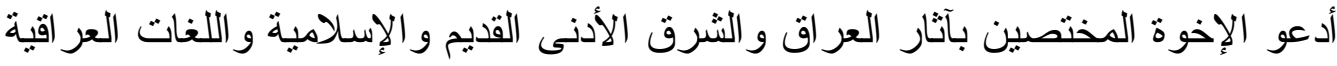

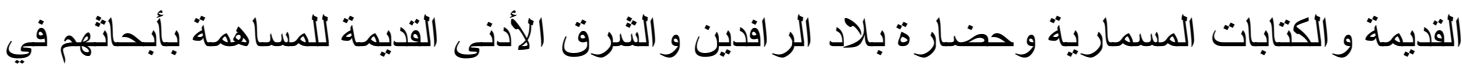

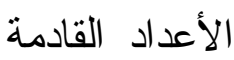

ومن الله التوفيق 



\section{حقوق الجار المتضرر في القاتون العراقي القديم}

\section{أ. م. د ع عبدالرحمن يونس عبدالرحمن}

كلية الآثار - جامعة الموصل

الماخص

إن ما نصت عليه القوانين العر اقية القديمة بشأن تتظيم العلاقات الاجتماعية بين أفر اد

المجتمع ومنها العلاقات بين الجيران وتحديد المسؤوليات و الو اجبات التي تقع على عاتق كل منهم وحماية حقوق الجار في أرضه ومسكنه و أمو اله وسمعته وشرفه ، يعطي تصور آ و اضحاً برقُقي الفكر القانوني في تتظيم العلاقات الاجتماعية والارتقاء بها نحو الأفضل ونحو بناء مجتمع أكثر تماسكأ في علاقاته بين أفر اده ـ واستتادا إلى ما ورد في النصوص القانونية فإن أكثر الأضر ار وروداَ في القو انين العر اقية القديمة كانت تللك المرتبطة بالحقول و الأر اضي الزر اعية ، ومن ثمَ الأضر ار النفسية والمعنوية فضلك عن الأضر ار المالية ، وقد ر اعى المُشرع في إقراره للمسؤولية الجزائية وفي استحصال الحق للجار المتضرر ، نوعية الضرر المُلحق بالجار، و مدى حجمه و القصدية في فحل الضرر ، ففي حالة التقصير و الإهمال غير المُتَعمد كانت العقوبة أخفّ وطأة منها في حالة التعدد و الر غبة في إيقاع الضرر بممتلكات الجار أو الاساءة اليه بتشويه سمعته و الطعن بشرفه أو القيام بسرقة أمواله أو التعدي على حقوقه أو غير ذلك من الأضرار الاخرى ـ ومقارنة مع ما ورد في بعض مواد القانون المدني العر اقي المعاصر فيما له علاقة بحقوق الجار فإن العقوبات و التعويضات التي سنها القانون المدني بشأن ذلك تكاد نكون مُخففة جداَ قياساً لما ورد في القو انين العر اقية القديمة ، وربما قد يكون العامل الأخلاقي في نظر مشرعي القانون المدني هو الأقوى في احتر ام حقوق الجار و عدم التجاوز عليها مما لم يدفع إلى

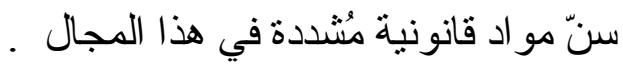




\title{
Rights of the affected neighbor in the Ancient Iraqi law
}

\author{
Assistant Professor Dr. Abdulrahman. y . Abdulrahman \\ College of Archaeology - University of Mosul
}

\begin{abstract}
The provisions of the Ancient Iraqi laws concerning the organization of social relations between the members of society, including the relations between neighbors and determining the responsibilities and duties that are incumbent on each of them and protecting the rights of the neighbor in his land, housing, money, reputation and honor, gives a clear perception of the legal thought in organizing social relations and upgrading them for the best And towards building a more cohesive society in its relations among its members According to what is stated in the legal texts, the most harmful reference in the old Iraqi laws were those related to the fields and agricultural lands, and then the psychological and moral damages as well as the financial damage. The legislator took into consideration the criminal responsibility and the right to the injured neighbor, the quality of the damage to the neighbor, In the case of negligence and negligence, the punishment was lighter than in the case of intent and the desire to harm the property of the neighbor or to abuse him by defaming his reputation and the challenge of honor or steal his money or infringement of his rights or otherwise $\mathrm{N}$ Other damage.
\end{abstract}


إنَّ من دو اعي الفخر و الاعتز از بالقو انين العر اقية القديمة أنها لم تكن الأسبق فحسب من

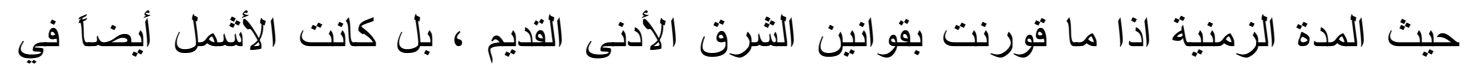

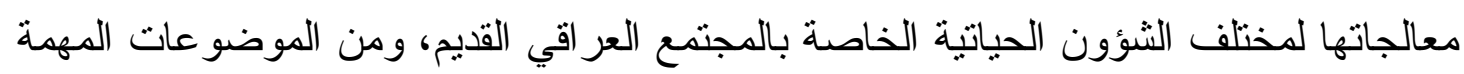

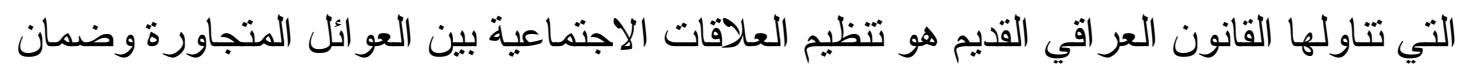

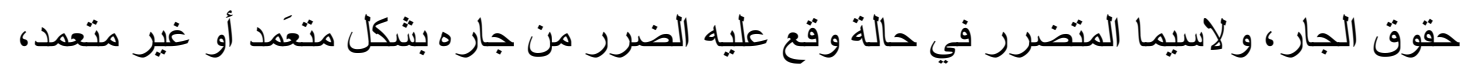

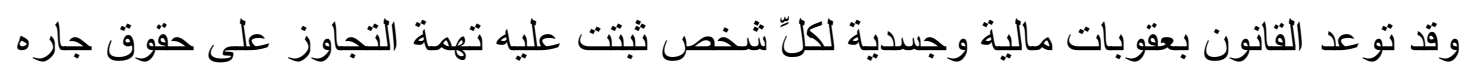

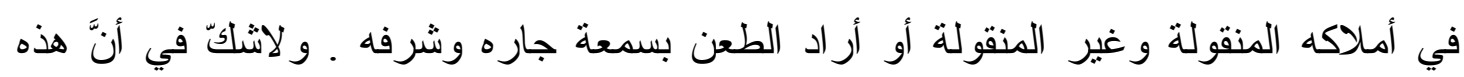
الاجر اءات القانونية كانت تهدف بالدرجة الاساس إلى المحافظة على بناء علاقات طيبة بين

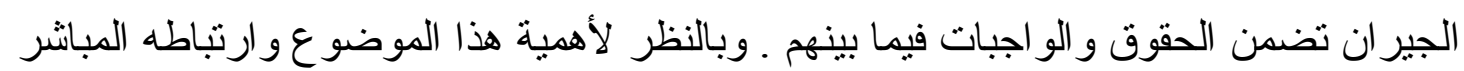

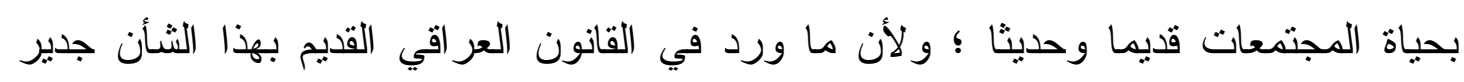

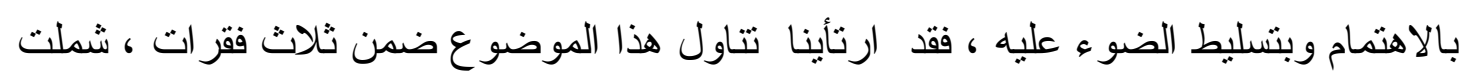
الاولى تسمية الجار وبعض ودلالته في اللغة العربية واللغات العر اقية القديمة ، وثنانياً مكانة

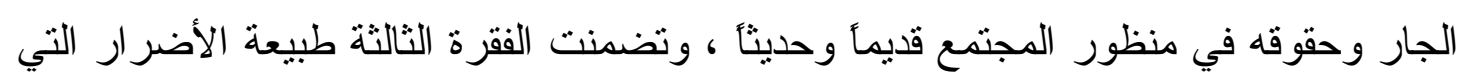

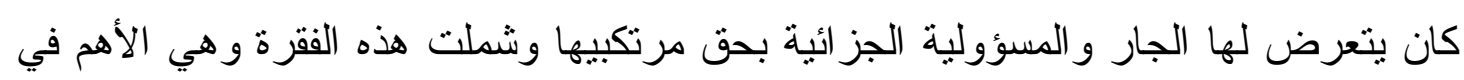

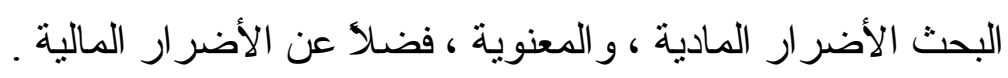




\section{أولاًَ- تسمية الجار ودلالته في اللغة العربية واللغات العراقية القديمة} وردت كلمة (الجار) في اللغة العربية بعدة معان، أحدها دالٌّ على المجاورة و الملاصقة في السكن كأن يُقال جاورهُ مُجاورة" ، وجورَّ ، أي: ساكنه و اصبح جار آله ، كذللك يقال (اجتَورَ) القوم ،أي: جاور بعضهم بعضاً ،(') وتصح قر اعة الكلمة بكسر الجيم (جو ارَ) ،أو بضمها وفتح

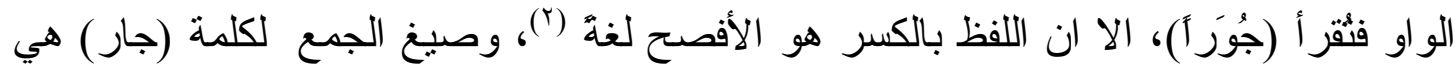

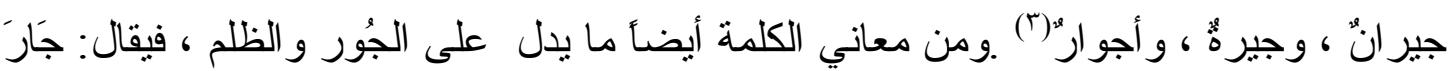

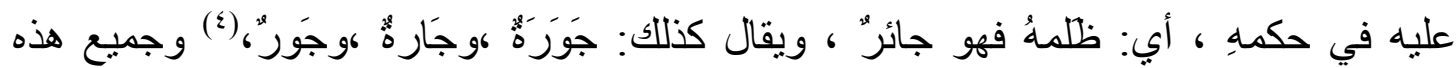
المفردات سو اء جاءت بصيغة المفرد أو الجمع تدل كما هو و اضح على الظلم و الجور ــ ومن اشتقاقات الكلمة ما بدل معناه على الاخول في حماية الآخر ، فيقال أن فلانأ (أجار) فلان ،أي: دخل في حمايته و أنقذه (0)، وكلمة (جَارَ أو استجار) تعطي مدلول المعنى المُشـار اليه آنفأ، وهي تطلق على الثخص الذي يرغب ان يُجار من قبل فلان (?)

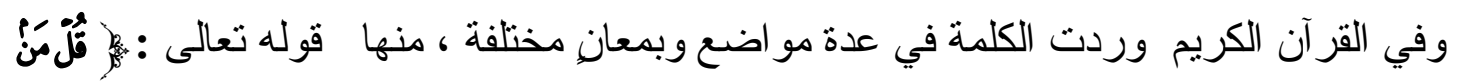

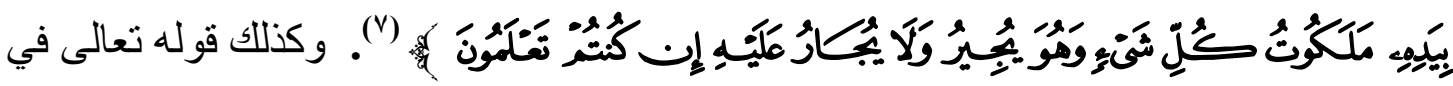

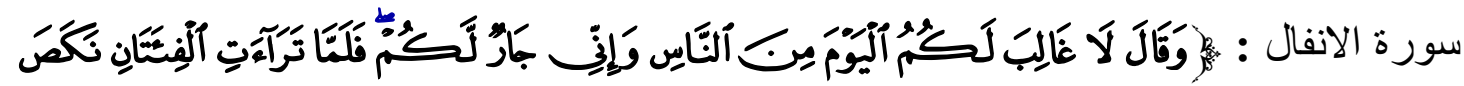

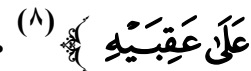

وفي اللغات العر اقية القديمة نجد أنّ هنالك من المفردات السومرية و الأكدية ما تدلّ على الجار و الجيرة و القرب ،ومن ذلك المفردة السومرية (DA) و تعني: بجانب أو بالقرب(9) ، ويقابلها في اللغة الأكدية المفردة (طيخ tehu ) وتأتي بمعنى: بجانب أو بجوار (•). و هذه الكلمة كما هو و اضح قريبة في اللفظ و المعنى من الكلمة العامية المستعملة في الوقت الحاضر (طخو) التي تعني لامسه أو احتلك به ـ. كذلك وردت الكلمة الأكدية (إتو itũ) للدلالة على الجيران

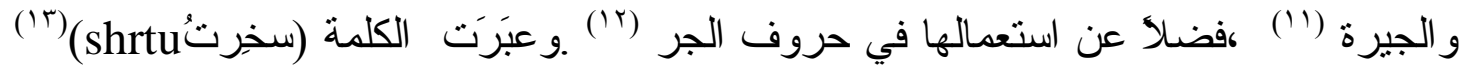
،المأخوذة من الفعلى(سخَارُsharu) عن المعنى ذاته الذي يدلِّ على الجو ار و الإحاطة (ءُ). أيضًاً من المصطلحات التي دلت على هذا المعنى كلمة (ahatu)، وكذلك (idatu) التي يقابلها في vإللغة السورية ايضأ المفردة (DA) المذكورة آنفاً ، وكلاهما يدلان على المجاورة والقرب(10) . 


\section{ثانياً_مكانة الجار وحقوقه في منظور المجتمع قديما وحديثا:}

مما لاشكّّ فيه أنّ أفضل من عبّر عن حقوق الجار و الوجبات التي ينبخي على الجار الالتز ام بها

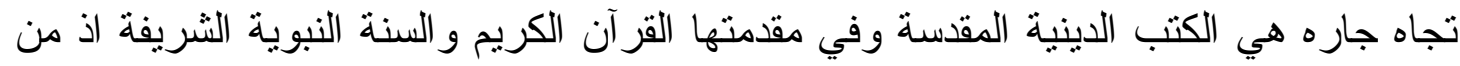

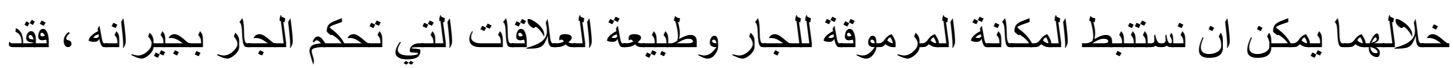
ورد ذكر الجار من ضمن الأصناف التي أوصى القر آن الكريم بالإحسان اليها، قال تعالى:

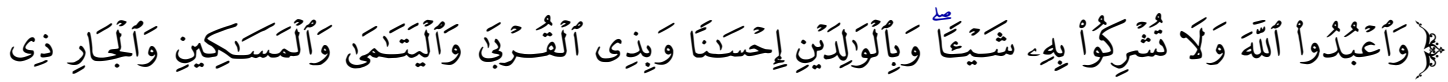

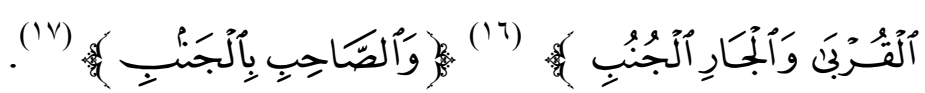
كذللك حثت العديد من الأحاديث النبوية الثريفة إلى ضرورة حسُن التعامل مع الجار

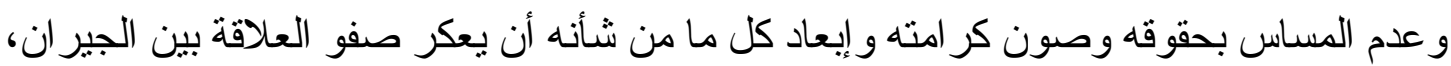
إذ جاء في الحديث الثريف عن ابن عمر و عائشة رضي الله عنهما ،ان رسول الله صلى الله عليه

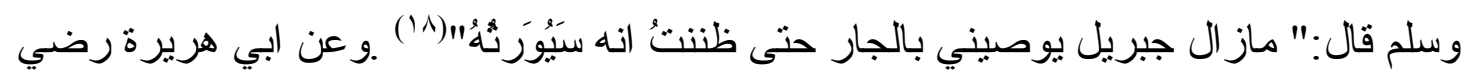

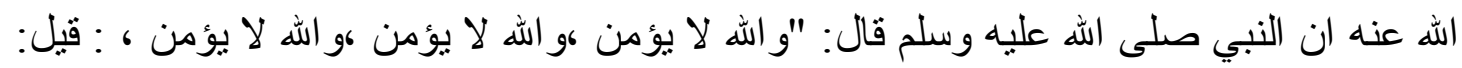

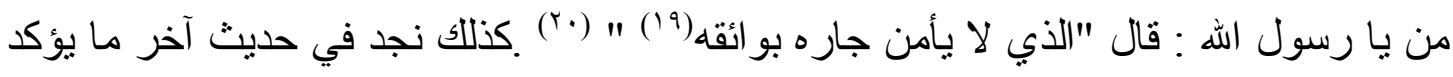

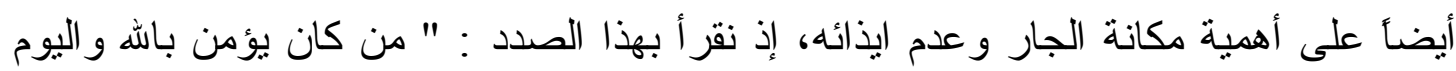
الآخر فلا يؤذِ جاره ..." (r(r)، و عنه صلى الله عليه وسلم قال: " من كان يؤمن باله و اليوم الآخر

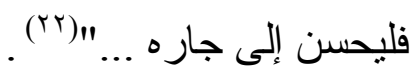
كما نجد أيضاً في كتاب العهد القديم ما يؤكد على ضرورة احتر ام الجار وعدم الاعتداء

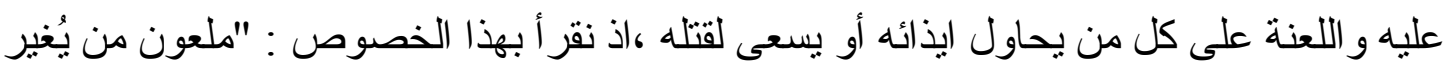

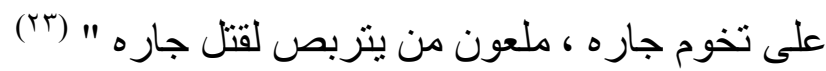
ومع ندرة المعلومات المتعلقة بطبيعة العلاقات الاجتماعية الي كانت تسود بين العو ائل

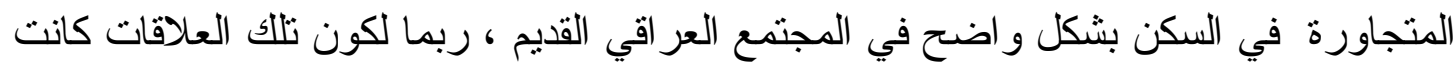
تتسم بشكل عام بحُسن الجوار وعدم وجود ما يعكر صفوها من الششاكل مما لم بدعُ إلى توثيقها

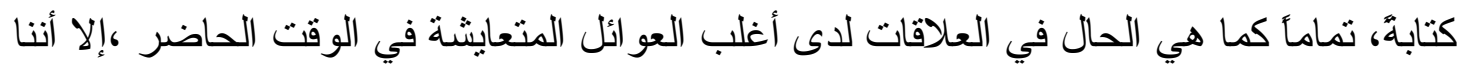

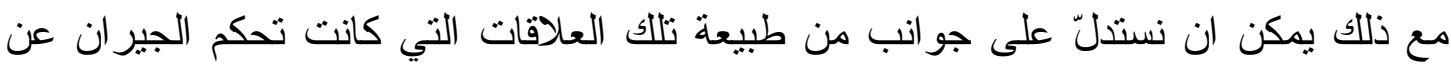
طريق ما ورد في النصوص القانونية التي وضحت حقوق الجار المتضرر و ألزمت الجار المسؤول عن الضرر بتعويض الجار المتضرر ماديا ومعنويا تبعأ لحجم الضرر ونوعه ، وهذا

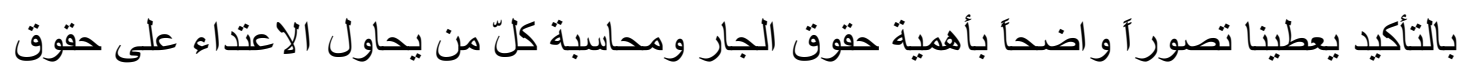

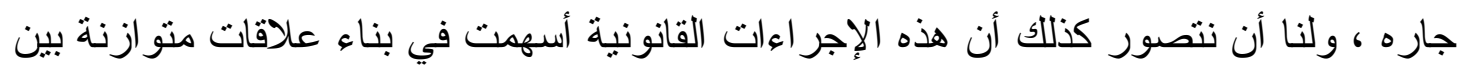


الجيران وخفقت من التجاوز على حقوق الآخرين ، وبسبب التقارب الدكاني وكثرة اللقاءات

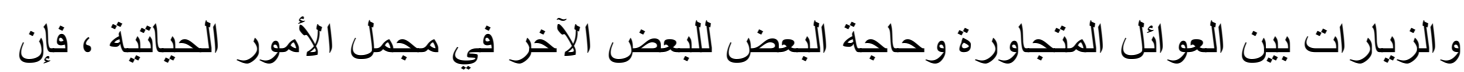
العلاقات الاجتماعية بين الجير ان ربما كانت تفوق في كثثر من الأوقات حتى العلاقات الأسرية ، وقد يستعير الجار من جاره ما يحتاجه من المو اد و المساعدة دون تَكلف أو خجل ، إلا أن الإكثار من تلاك الطلبات و المداومة عليها بحسب رأي أحد الباحثين كان يقلل من مكانة الجار و احتر امه ونه

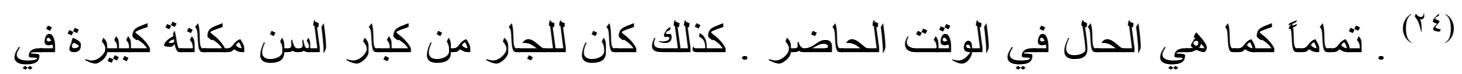
مناطق سكناهم وكان البعض منهم يُستدعى للإدلاء بشهادته ممن هو مطلع على حقوق جاره كما يرد ذلك "في قضية دعوى قضائية أقامها رجل على آخر عن ملكية قطعة أرض بين داءئ داريهما أدلى كبار السن من الجير ان ممن كان يتذكر و الدي الخصمين بشهادتهم فيما يتعلق بعائديه تلكي

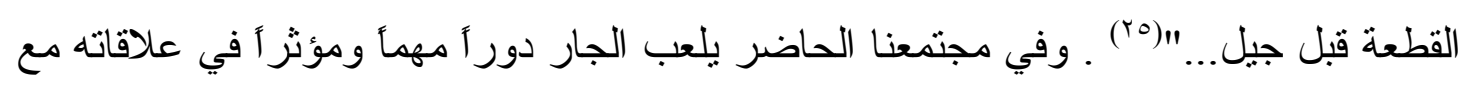

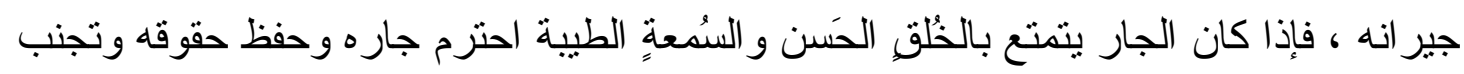

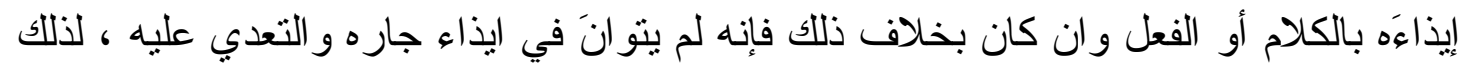

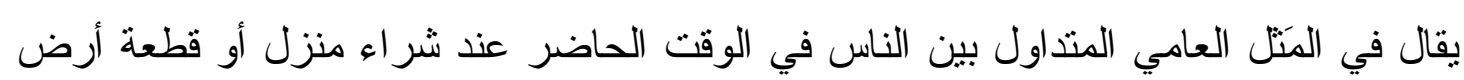

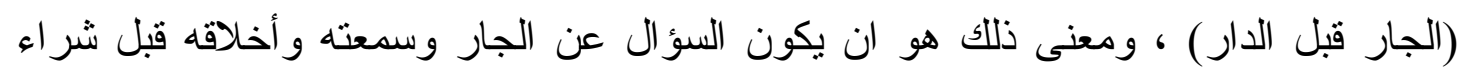

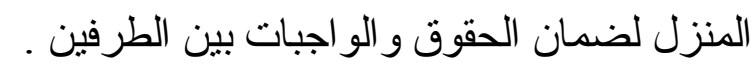




\section{ثُالثاًـطبيعة الأَضر ار والمسؤولية القانونية بحقّ مرتكبيها: 1 _الأَضرار المادية _التجاوز على حدود أملاك الجار: أ_الحقول والأراضي الزراعية:}

الضَرر في اللغة العربية هو الحاق الأذى و الكره بالآخرين ، فيقال: (ضرَّهُ) ضرَرَ

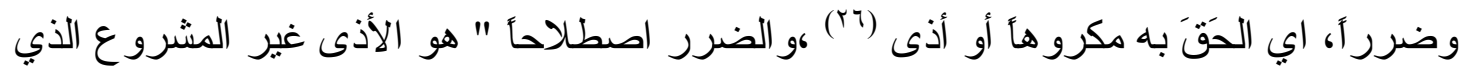
يصيب الانسان في جسمه أو ماله أو شعوره وقد عَدَت القوانين العراقية القديمة ومنها قانون حمور ابي على وجه الخصوص الضرر ركنأ أولياً لقيام المسؤولية التقصيرية؛ لأن التعويض لا يكون إلا عن ضرر أصاب طالبه فنقوم المسؤولية من أجل تعويضه ويقدّر قدره فإذا انتفى

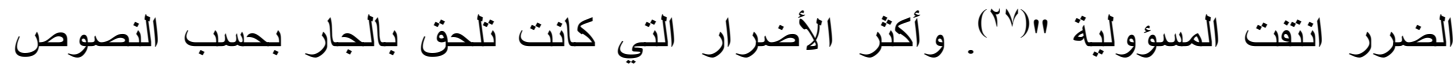
القانونية كانت تلاك المتعلقة بالتجاوز على حدود أملاك الجار غير المنقولة منمثلة بالحقول

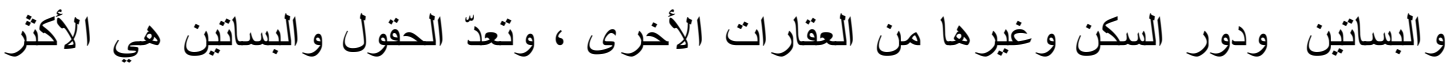

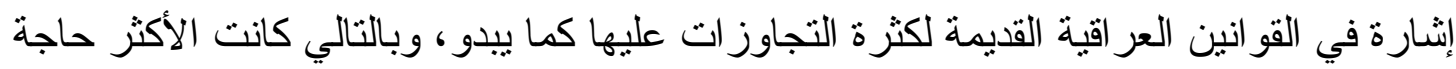
لوضع الضو ابط القانونية التي تحكم العلاقة بين الجيران و إنصاف الجار المتضرر من الجار

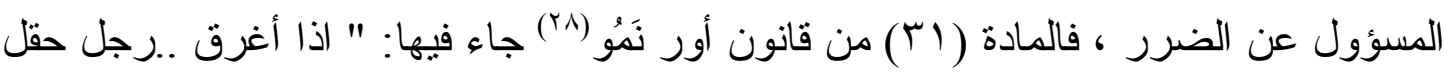

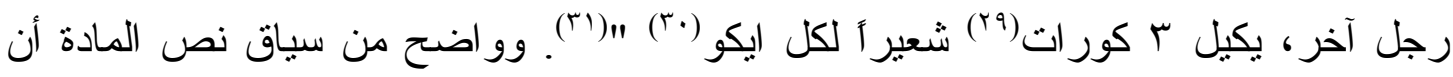

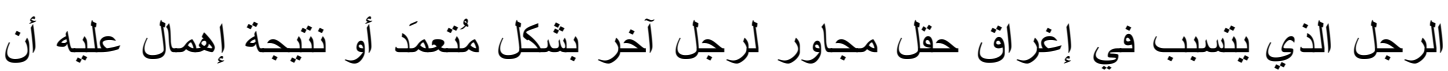
يعوض صاحب الحقل المتضرر بقدر الضرر الذي وقع عليه وبنسبة ثلاث كور ات من الثعير

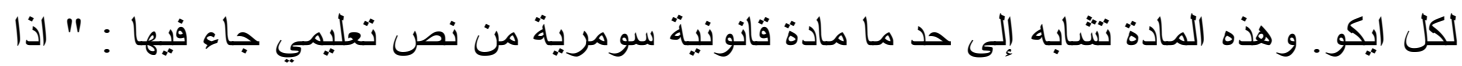

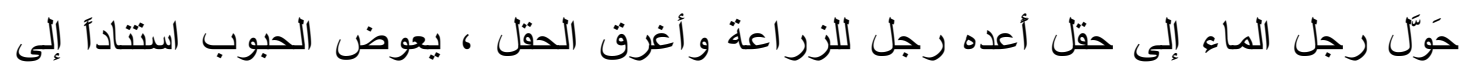

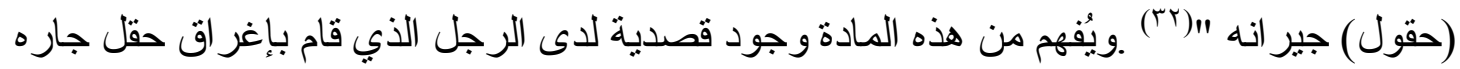
المُعَ للزر اعة وعليه فإن القانون ألزمه بتعويض كامل الحقل من المحصول استتاداً إلى نتاج الحقول المجاورة .وتعالج المواد(به_هo) من قانون حمور ابي إنثكاليات التجاوز على الحقول و الأر اضي الزر اعية وبضمنها الحقول و البساتين المتجاورة. وقد حدد القانون مختلف أنواع التجاوز ات و استتد على مبدأ قانوني سليم في التعويض بتحمل فيه الفلاح المتعدد بتجاوزه على ولى لهاني

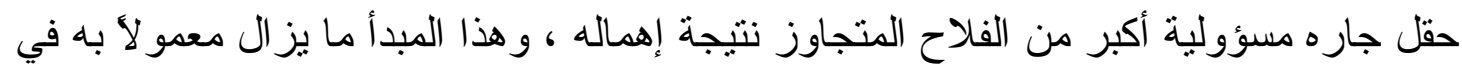

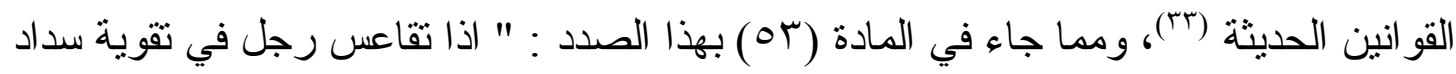

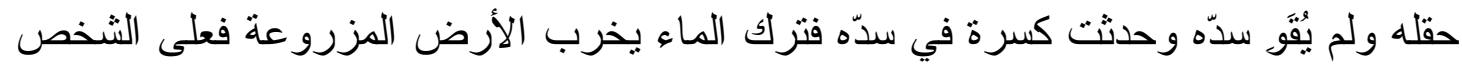

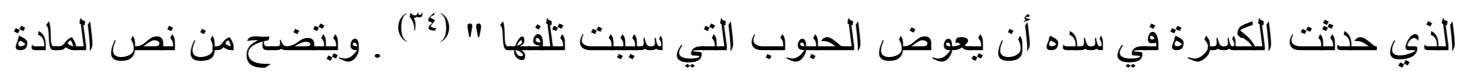


المذكورة آنفاً أن الضرر الذي وقع على حقل الجار كان بسبب إهمال الفلاح وتقصير في إصلاح

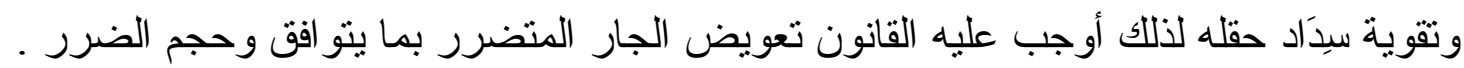

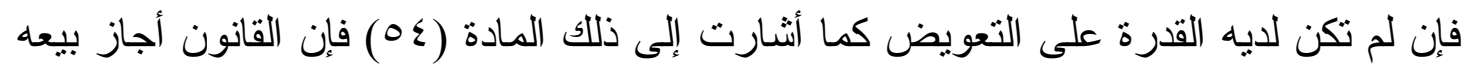

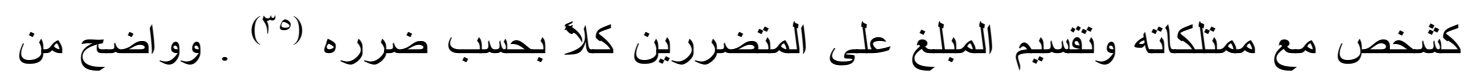

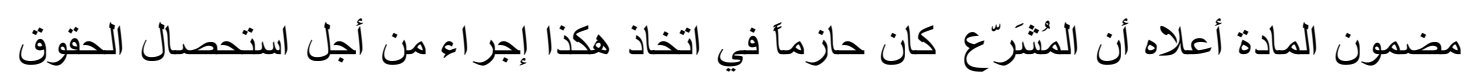

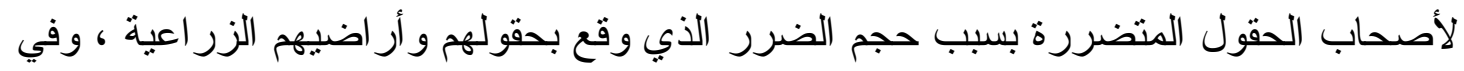

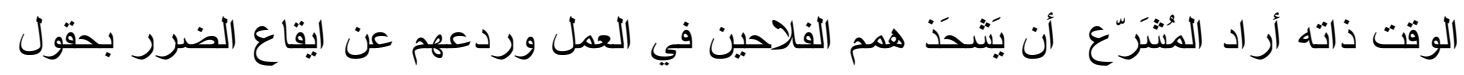

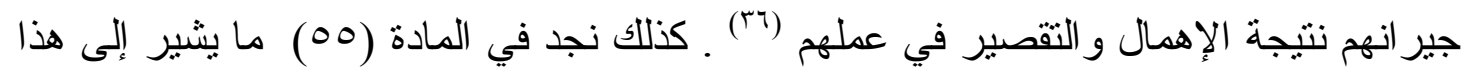
المفهوم إذ جاء فيها: " اذا فتح رجل جدوله للسقي وتقاعس وتسبب في أن تجرف المياه حقل فئل

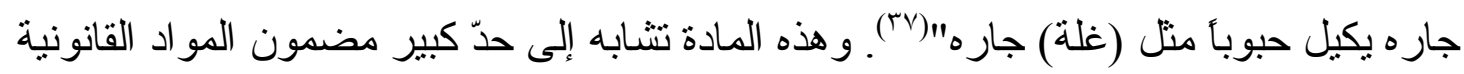
السابقة وعلى الفلاح الذي تسبب في هذا الضرر أن يعوّض المتضرر في حقله بما يقابل انتاج

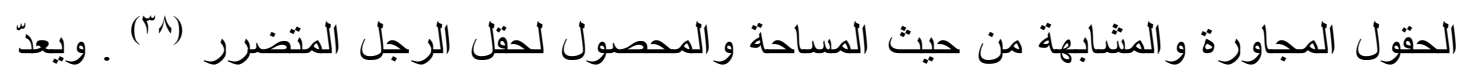
هذا المبدأ اي التعويض تبعأ للمسؤولية التقصيرية من أهم مصادر الالنزام في قانون حمور ابي

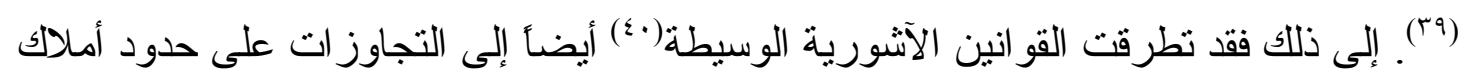

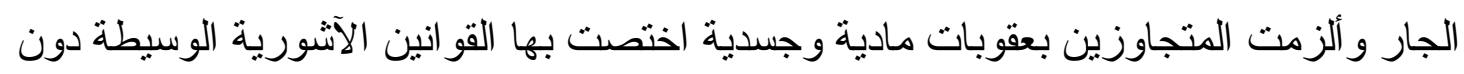

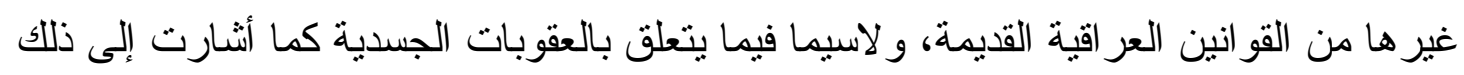

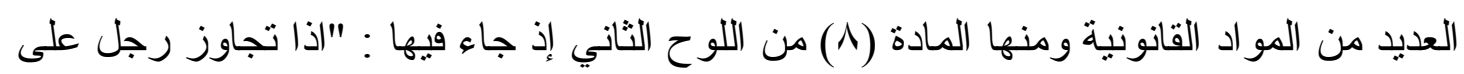

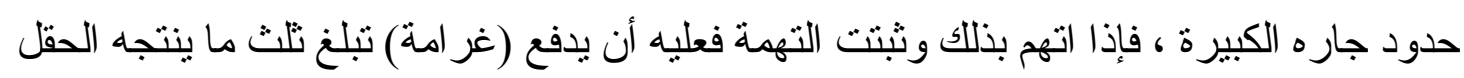

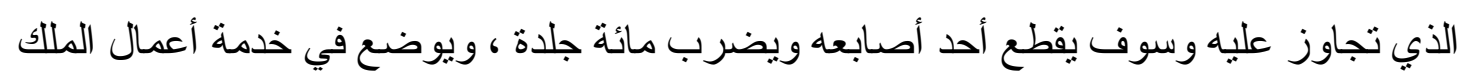

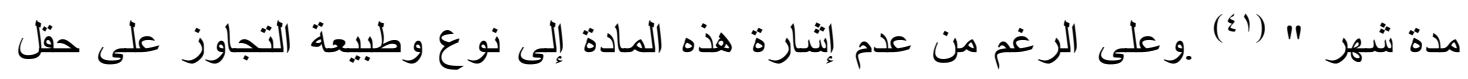

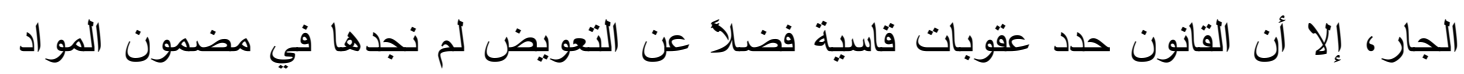

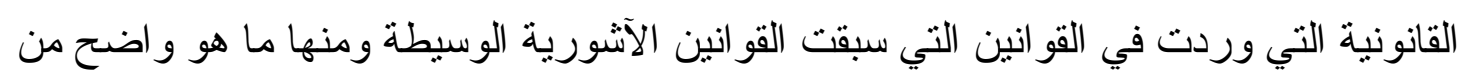

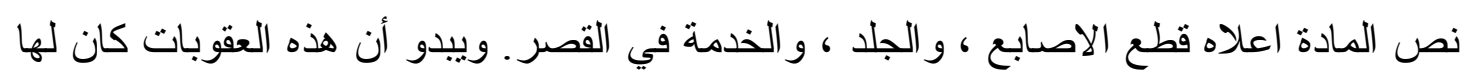

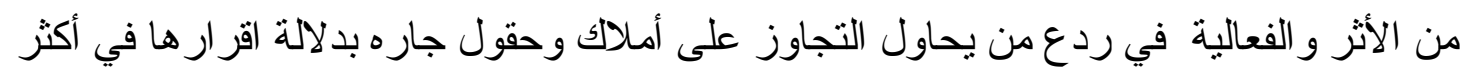

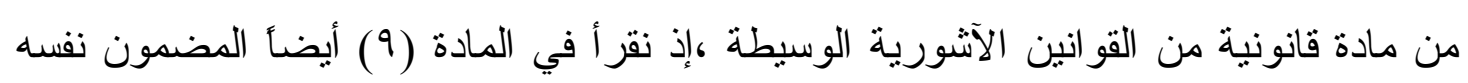

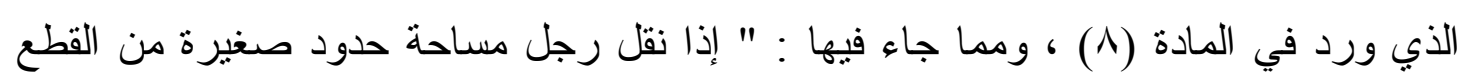

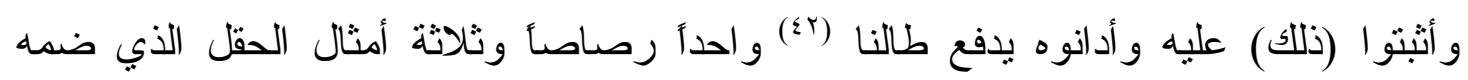

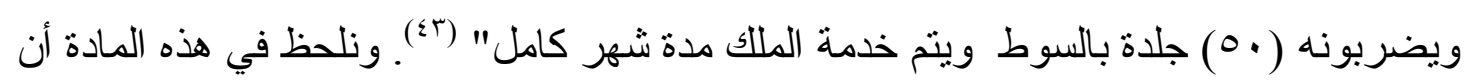

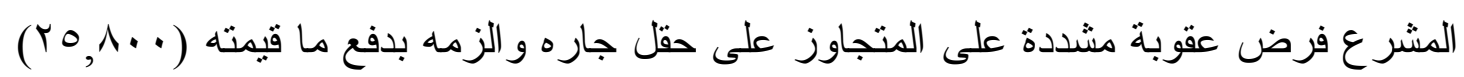


كغم من الرصاص فضلا عن ثلاثة أمثال الحقل الذي ضمه إلى حقله ، ويضرب بالسوط خمسين

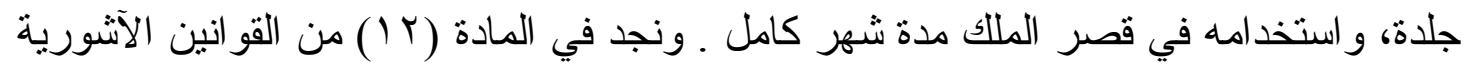

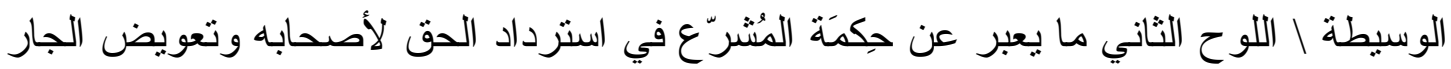
المتضرر بما يتتاسب وحجم الضرر، ومما جاء في نص هذه المادة : " إذا غرس رجل بستانا

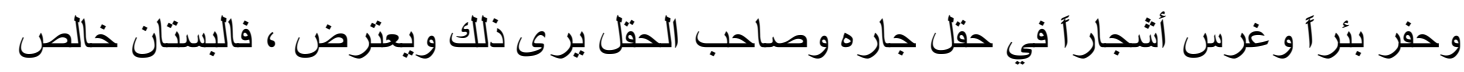

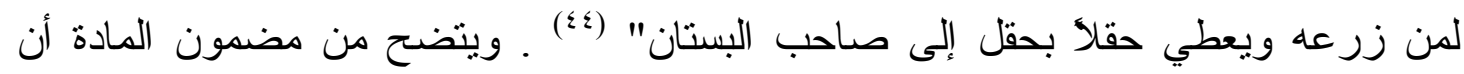
التجاوز على حقل الجار و استخدامه للأغر اض الزر اعية كان قد تم بالقوة ومن دون موافقة صاحب الحقل المتضرر ، وبناءً على ذلك أوجب القانون على الثخص المتجاوز استقبال الحقل

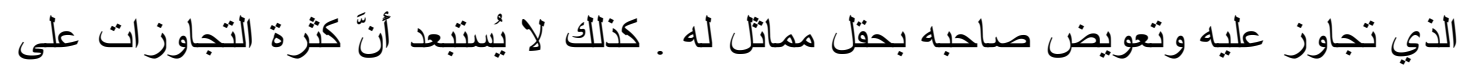
حقوق الآخرين ومنهم على وجه الخصوص الجير ان هي التي دفعت المُشرّع الآثشوري إلى اتخاذ أقسى العقوبات بحق المتجاوزين للتقليل من هذه الظاهرة و الحدّ منها ـ ونجد من العصر البابلي

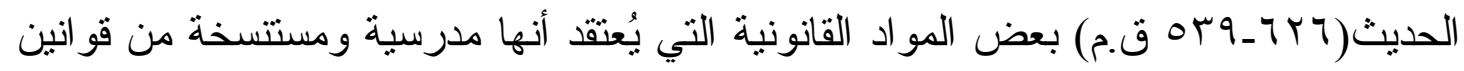

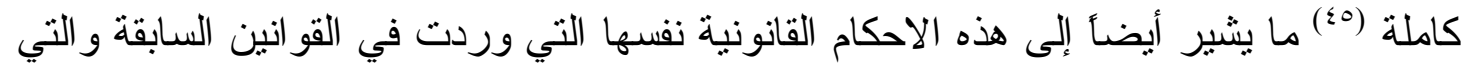
كان الهدف منها هو استحصال حقوق الجار المنضرر ممن تسبب في ضرر جاره ، ومما جاء في المادة (r) من القوانين البابلية الحديثة : " الرجل الذي فتح بذره للسقي ولم يقو جوانبه

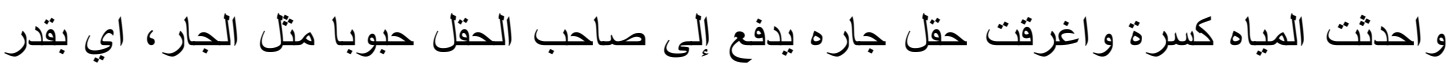

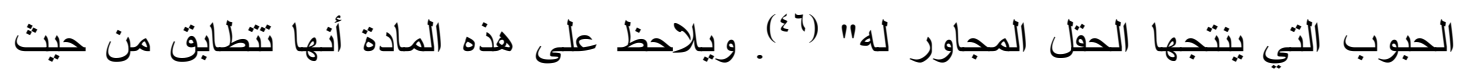
المضمون وقيمة التعويض مع ما ورد في المادة (rه) من قانون حمور ابي ـ وفي مقارنة يسيرة

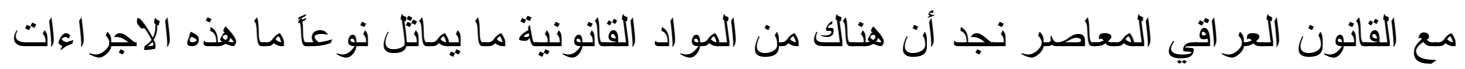

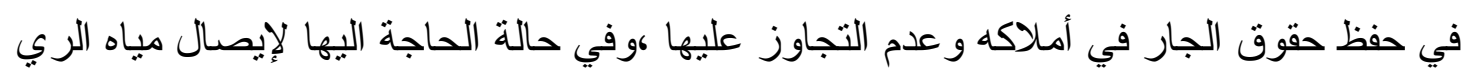

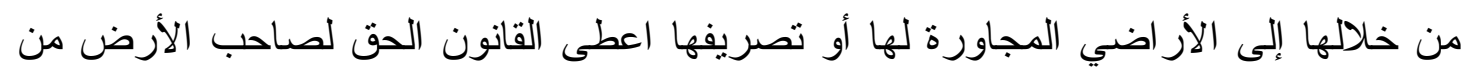

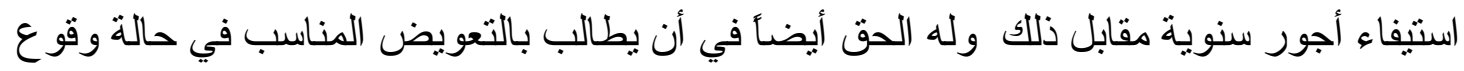

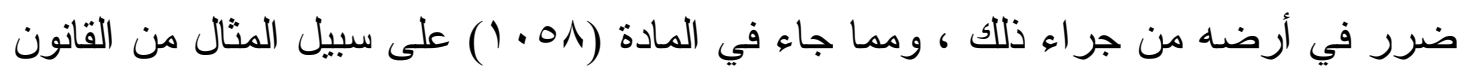

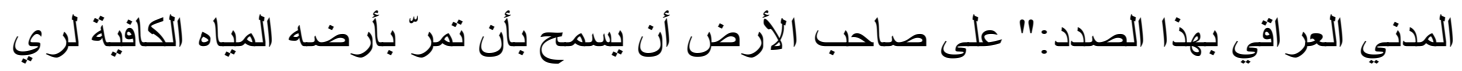

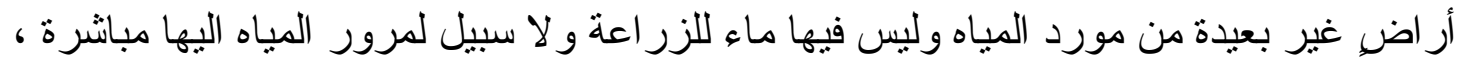

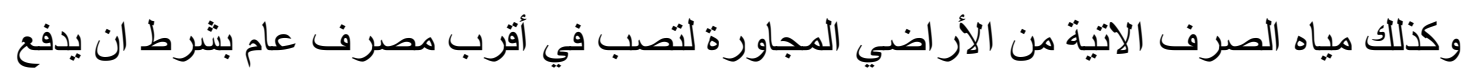

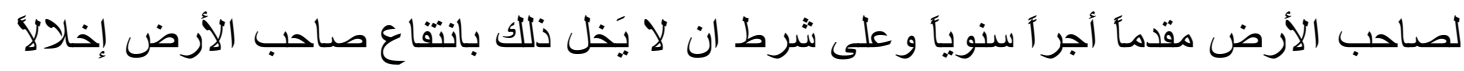

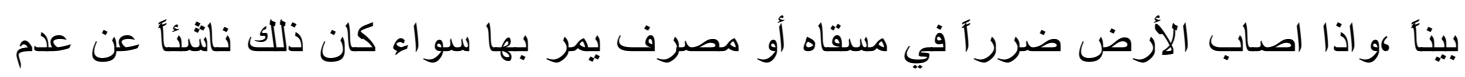

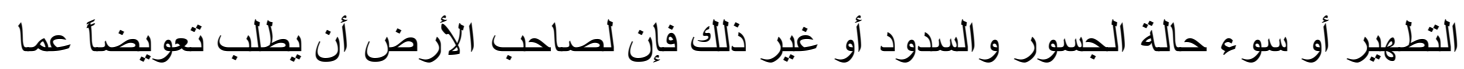


أصابه من ضرر" (V)". وو اضح من نص هذه المادة أن القانون ألزم صاحب الأرض بإمكانية

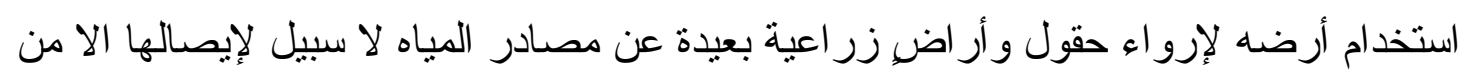

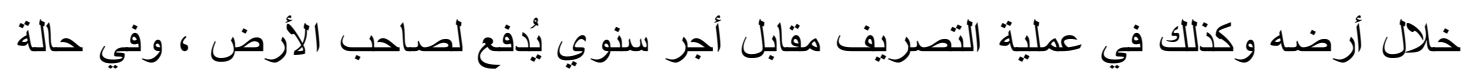

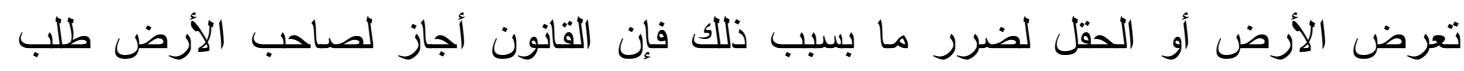

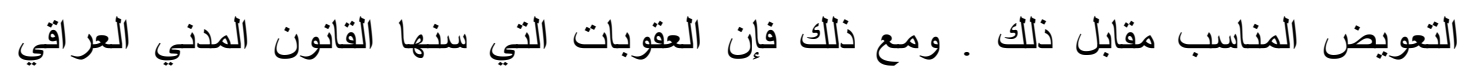

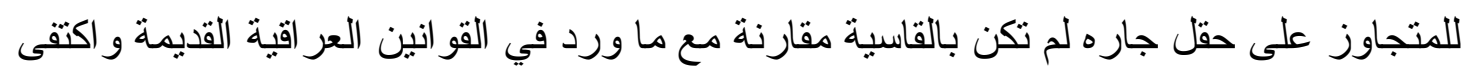

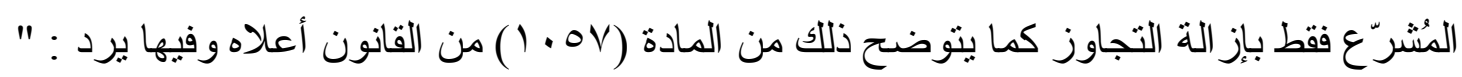

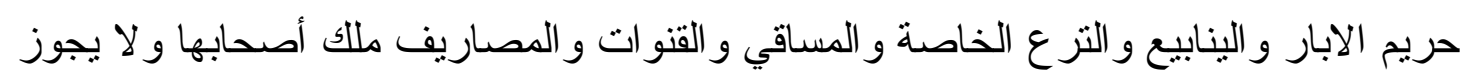

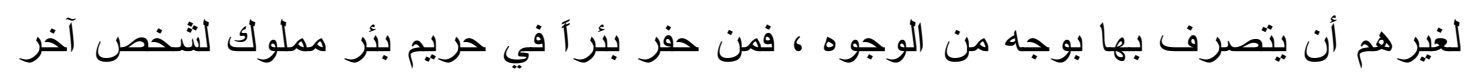

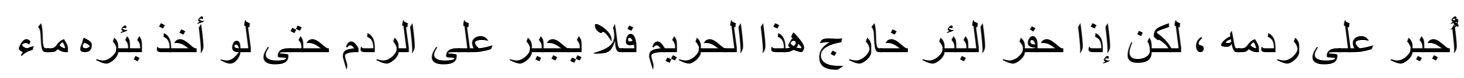

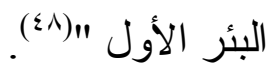

\section{بـ الاور والأَراضي السكنية:}

إلى جانب التجاوز على الحقول و الأراضي الزر اعية وهي الأكثر حضوراً في القوانين

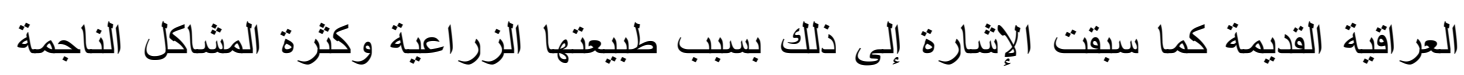

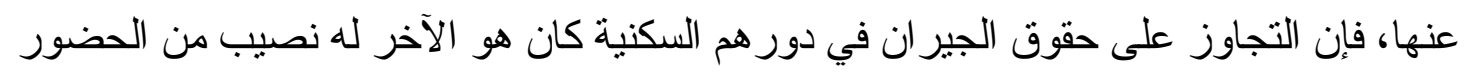

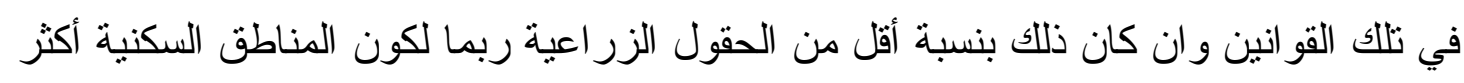

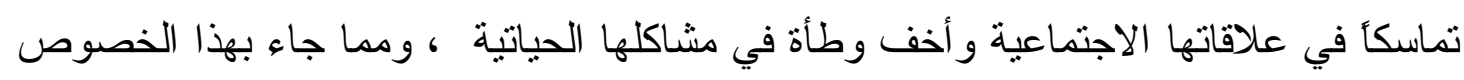

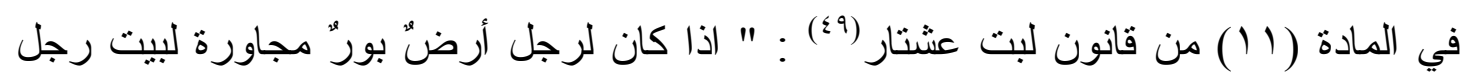

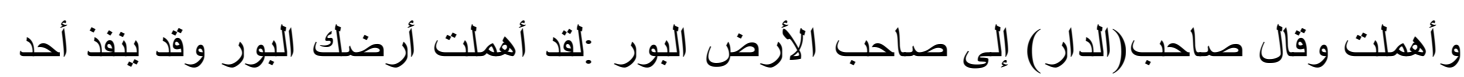

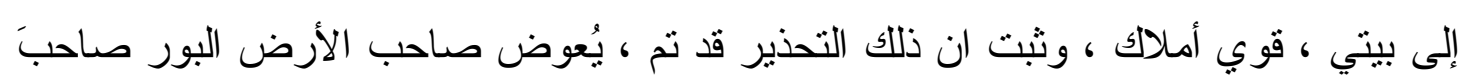

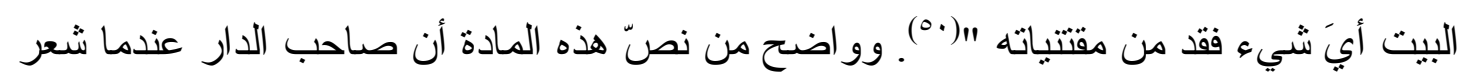

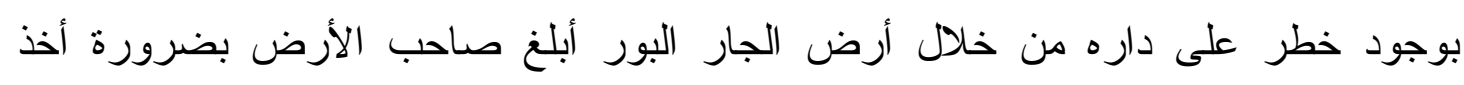

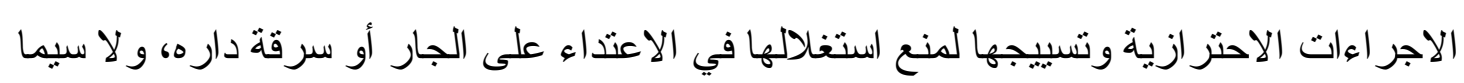

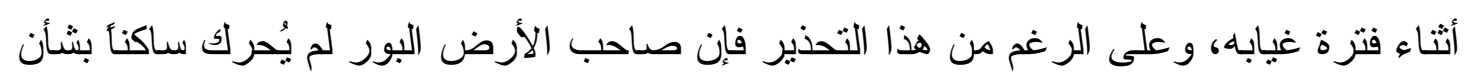

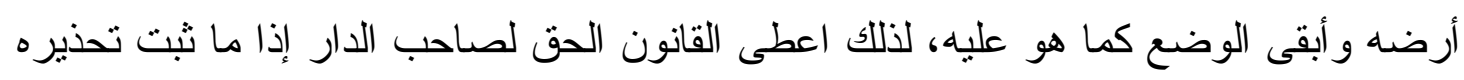

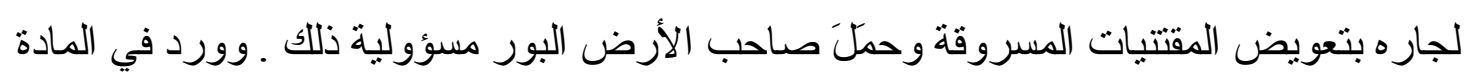

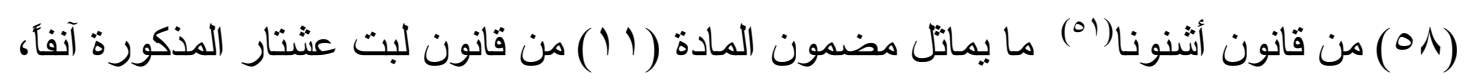

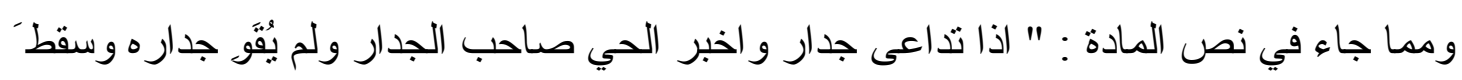


الجدار ، و امات ابن رجل ، انها قضية نفس (تطبق) مر اسيم صمدات شرم"(ه广هـ ويعني ذلك ان

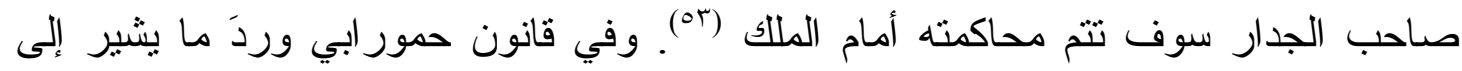
الاهتمام بحقوق الجار المنضرر من قبل املالك جاره والمسؤولية التي تقع على عاتق الجار

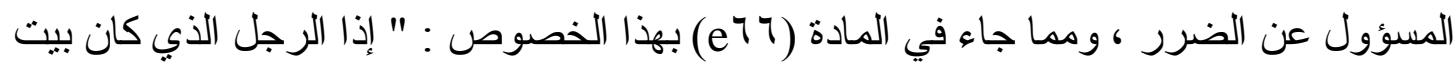

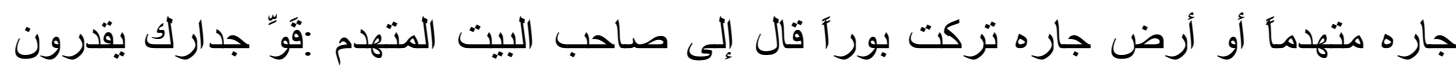

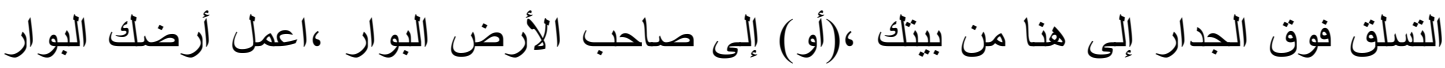

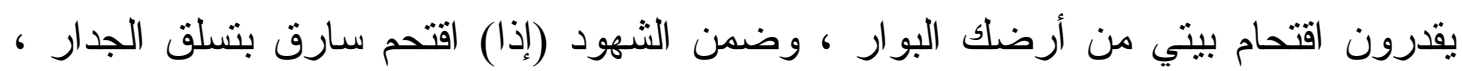

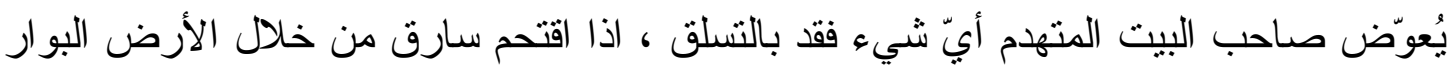

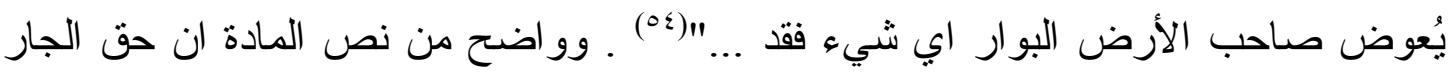

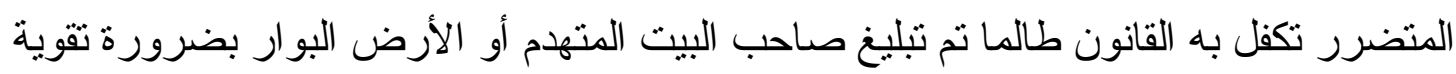

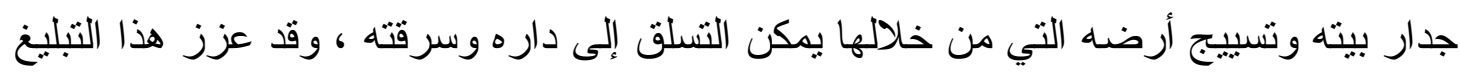

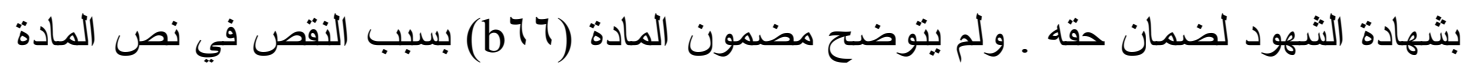
وتلفها إلا أنها كما يبدو متعلقة أيضأ بحقوق الجار استتادأ إلى ما ورد في المادة التي سبقتها وتلكاد التي أعقبتها(00). كذللك ورد في المادة (177) من قانون حمور ابي ما يشير إلى الاجر اءات التهات

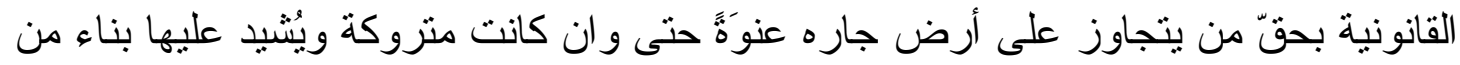

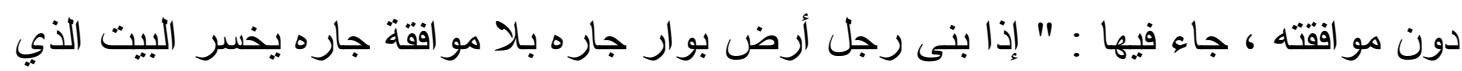

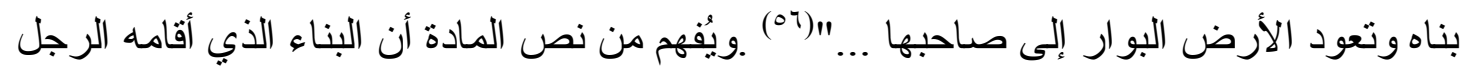
على أرض جاره من دون مو افقته هو باطل ويدخل في مفهوم التجاوز على حقوق الجار و عليه فإن القانون كان إلى جانب صاحب الأرض في استرداد أرضه بالبناء المشيُّيد عليها أو بدونه

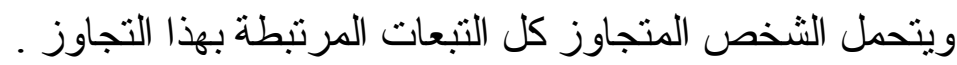
ومثل هذه القضايا وغير ها كان ينم الفصل فيها عن طريق المحاكم وعن طريق جهاز خاص يتكون من القضاة و العاملين معهم في هذا السلك القانوني وكان للمو اطن الحق في اقامة دعوى قضائية ضدّ من ظلمه أو تجاوز على حقوقه في أملاكه الخاصة أو على حريته الثخصية

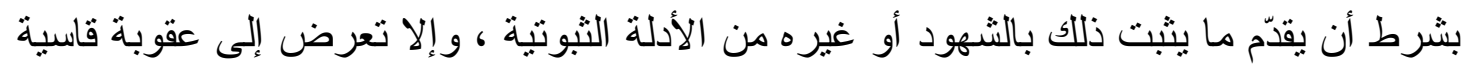

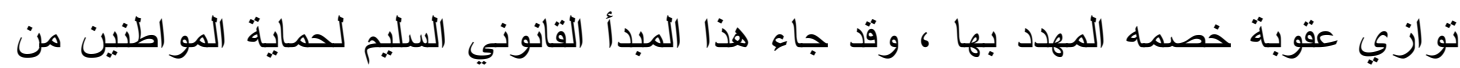

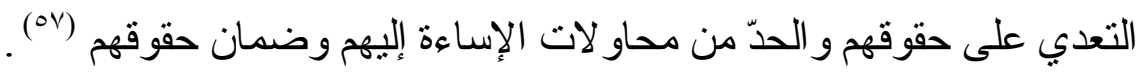




\section{r-الأَضرار النفسية (الطعن بسمعة الجار وشرفه):}

إلى جانب الأضر ار المادية فقد يتعرض الجار إلى سوء المعاملة من جاره لسبب ما قد يُفضي إلى تدهور العلاقة بينهما ويدفعه إلى استعمال كلمات نابية تَحط من قدر جاره وتطعن في سمعته وشرفه وقد حذر القانون من هذا الاسلوب الرخيص الذي يضر بسمعة العائلة وشرفها في حالة عدم وجود دليل يثبت اتهامه الباطل لجاره واعطى الحق للجار المتضرر في استحصال الحق عن طريق القانون وفرض أقسى العقوبات بحق المتجاوزين على حقوق الآخرين ، وقد جاء في المادة (1 ( ) من القو انين الآثورية الوسيطة \اللوح الأول بهذا الخصوص ما يأتي: " اذا قال رجل لجاره سرَ أو في مشاجرة : ان الناس يضاجعون زوجتلك ، اقدر ان اثبت عليها ، طالما لا يقدر على اثبات ذلك عليها (أو) لم يثبتو ا ذلك يضربون ذلك الرجل ع جلدة بالسوط (و ) يعمل في خدمة الملك شهر أ كاملا ويقصون شعره ويدفع ا وزنة رصاصاً "(م)( . . وو اضح من نص هذه المادة ان الرجل الذي يحاول ان يُشَهِر بسمعة جارهوشرفه ولم تكن لديه الأدلة على ذلك فإن القانون توعده بأقسى العقوبات بسبب ادعائه الباطل و إدلائه بمعلومات كاذبة كان الهدف منها هو النيل من سمعة جارهوشرفه ــ العقوبة نفسها ايضأ تتطبق على الثخص الذي يتهم جاره بالباطل بممارسة فعل اللواطة ، اذ نصت المادة (9 (1) من القوانين ذاتها إلى ما يأتي: " إذا بثّ رجل الثائعة ضد جاره في السر قائلا : إن الناس يضاجعونه ، أو انه قال له في مشاجرة أمام آخرين : ان الناس يضاجعونك ، سأثبت ذلك ، عليك ، طالما لا يقدر اثبات ذلك عليه (و) ولم يدنه ، يضربون ذللك الرجل • م جلدة بالسوط ويتم خدمة الملك شهر آ كاملا ويقصون شعره (و) يدفع وزنة رصاصأ" (09) ـوكما هو و اضح فإن مضمون هذه المادة يتشابه إلى حدّ كبير مع ما ورد في المادة السابقة لها وهي ترتبط بسمعة العائلة وسلوكها الاخلاقي ، لذلك كما يبدو جاءت العقوبة متشابهة بحق من يُقدم معلومات مضللة و غير دقيقة ولم يتمكن من إثباتها ( (7). و على الرغم من قسوة العقوبات التي سنها القانون الآشوري الوسيط في المواد المُشار اليها آنفاً بشأن الاتهام الباطل من الثخص ضدّ جاره ، إلا أن القانون لم يحدد بشكل و اضح طبيعة رد الاعتبار للجار المتهم و اكتقى بالحق العام كما يبدو من دون الإشارة إلى الحق الخاص. إلى ذلك فإن المادة (· ( ) من القو انين الآثورية الوسيطة \اللوح الاول تتاولت ايضاً عقوبة من يرتكب فعل اللواطة مع جاره ، فاذا ثبتت التهمة ضده وكان السبب في التعدي على حقوق جاره و أدين بهذا الفعل فإن القانون حدد عقوبة ذلك بالمثل على القائم بهذا الفعل المشين ثم يُخصى لمنع العودة من ممارسة

هذا العمل السيء مرةًَ اخرى (7) 


\section{ץ-الأَضرار المالية (اتهام الجار بعدم حفظ الأمانة والسرقة):}

من الأضر ار التي أثنار إليها القانون وفيها تعدٍٍ على حقوق الجار هو توجيه الاتهام الباطل في حفظ الامانة فإذا بالغ رجل بتقييم الوديعة التي أودعها لدى جاره وثتبت ذلك بشكل تحريري ، فإن أقيمت دعوى قضائية ضدّه وثبت انه بالغ بتقييم وديعته فإنه يكون أمام المُساعلة القانونية ويتعرض لعقوبات يقررها الملك (זr) كما نشير إلى ذلك المادة (• () من القوانين الآشورية الوسيطة \اللوح الثالث إذ جاء فيها : " اذا بالغ رجل بالأمانة عند جارهو أثبتو ا (ذللك) عليه (و)

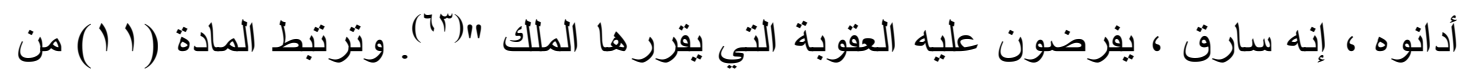
القو انين أعلاه بالمضمون نفسه أيضاً الذي ورد في المادة (• ( ) إذ يتعرض الرجل الذي بالغ في ادعائه لقيمة الوديعة عند جاره بعقوبات قاسية ومنها الجلد بالسوط (\&). إلى ذلك فإن المادة ( (1) من القو انين الآشورية الوسيطة \اللوح الخامس، على الرغم من النقص الحاصل فيها بسبب التلف إلا أنها تشير إلى عقوبة الشخص الذي ينتهك حقوق جارهويُغير على قطيع جاره من أجل السرقة ، ومما جاء في نص هذه المادة :" إذا.... الاغنام التي ....و إذا ....من قطيع جاره .... يُغير .... يضربون الذي أخذ الشاة . . 1 جلدة بالسوط (و) يجرون شعره ويتم خدمة الملك شهرَ كاملا ويكون مسؤو لا عن سرقة الشاة " (70) ويتضح من هذه المادة ان القانون لم يكتف بفرض ره العقوبة الجسدية على القائم بالسرقة فقط وانما ألزمه بتعويض جار ه للثياه التي سُرقت منه . 


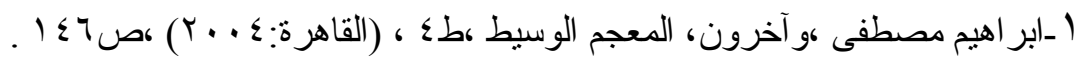

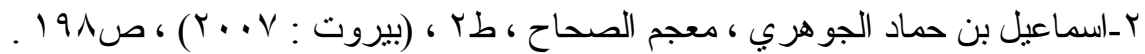

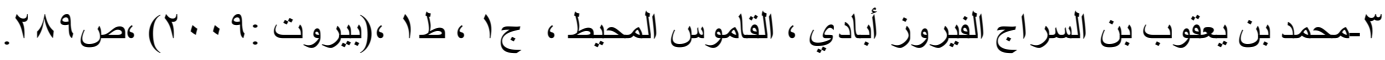

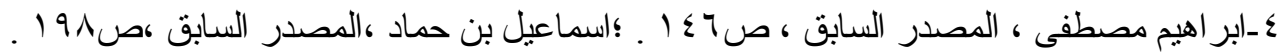

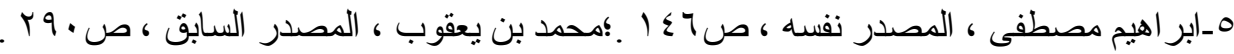

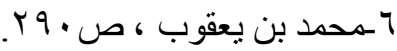
Vسورة المؤمنون ، اية :NA ـ؛ حول تقسير هذه الأية ينظر: ابن كثير ، تفسير القران الكريم ،ج؟ ،(بيروت ror (191.:

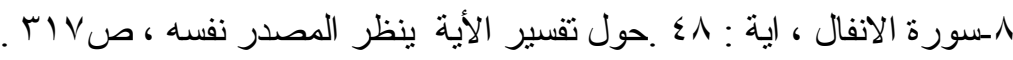

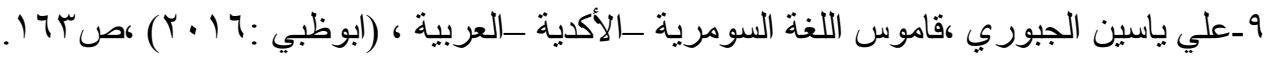
• ا ـامين عبدالنافع امين ، صيغ العقود البابلية في النصوص المسمارية ، رسالة ماجستير غير منشورة

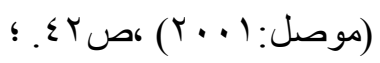

AHW :Vonsoden, Akkadisches Hand Wörte buch (Wiesbaden:1959),p.1383b.

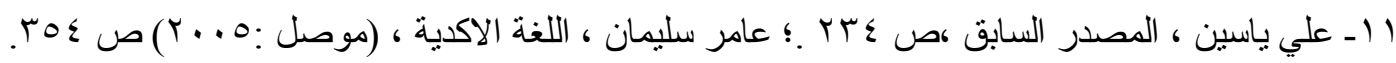
CAD, 1,j,vol.7,p,312

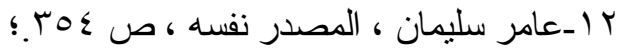

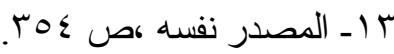

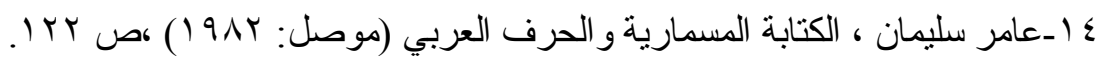
1 إرينة لابات ، قاموس العلامات المسمارية ،ترجمة البير أبونا ،واخرون ، المجمع العلمي

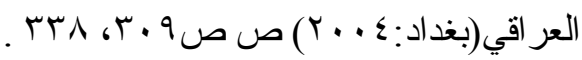

7 ايقصد بالجار ذب القربى أي الذي بينك وبينه قر ابة ،و الجار الجنب :الذي ليس بينك وبينه قر ابة ، ابن كثير ،

$$
\begin{aligned}
& \text { المصدر السابق ،صع 9؟. } \\
& \text { Vاسسورة النساء ،أية : جس. }
\end{aligned}
$$

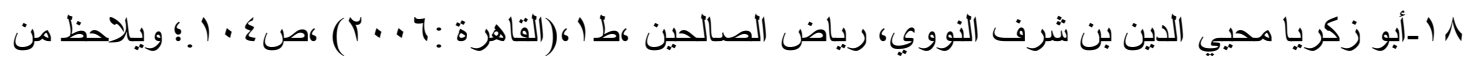
الحديث المكانة الكبيرة للجار إلى درجة أن النبيّ عليه الصلاة والسلام ظن أن الوحي سينزل https: Ilfathkker.blogspot.com. بتوريثه.

9 اـالبو ائق نعني الغو ائل و الثرور ، فالجار الذي يتوقع من جاره الأذى و الثر فهو لا يأمن شرهو لا يأمن ان يخلفه في أهله أو في ماله أو في ولده ـ ينظر :موقع خالا بن عنمان السبت: https $\underline{\text { Ikhaled al sabt .com }}$

$$
\begin{aligned}
& \text { •Y_النووي ، المصدر السابق،صه • 1. } \\
& \text { 1.ب_المصدر تفسه ،صه • 1. } \\
& \text { Y Y_المصدر نفسه ،ص ص } 0 \text { • 1_T · I. }
\end{aligned}
$$


كب-جورج بوييه ، المسؤولية الجز ائية في الاداب الاشورية و البابلية ، ترجمة سليم الصويص ، (بغداد : (191) )

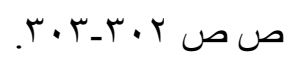

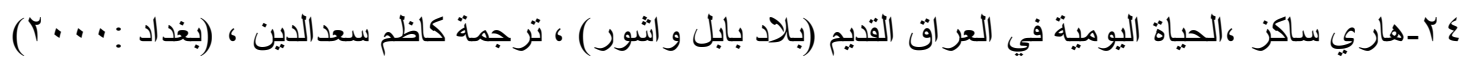

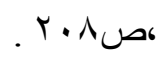

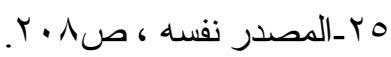

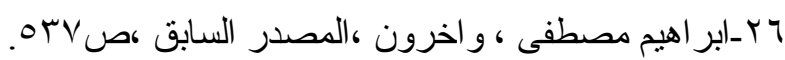

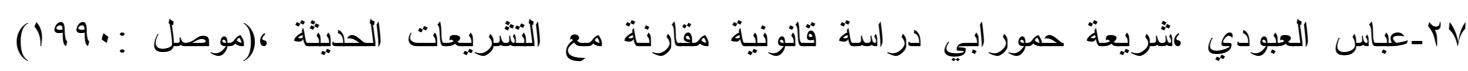
كص. 19. ^ץ-سمي قانون اورنمو باسم مشر عه الملك اورنمو مؤسس سلالة اور الثالثة ويضم ما يقارب (Y (r) مادة قانونية دُونت باللغة السومرية .عن هذه المو اد ينظر :

Martha.T.Roth, Law Collection from Mesopotamia and Asia Minor, 2ed,(Atlanta:1997),pp13-21.

9r _الكور هو من المكاييل التي استخدمت في العر اق القديم ويعادل ما قيمنه في الوقت الحاضر (T، Y Y Y). مؤيد

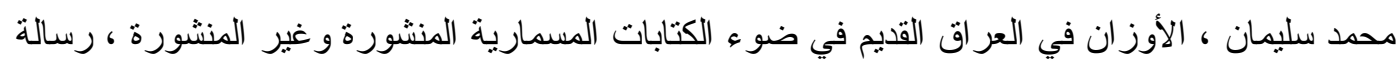

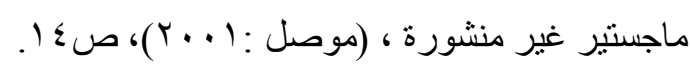

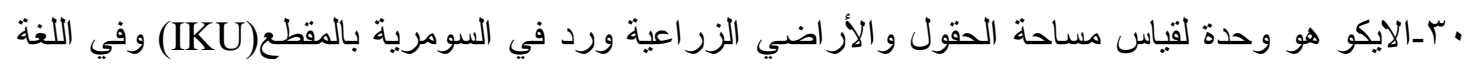
الأكدية بالمقطع(iku) ويعادل في مقاييس الوقت الحاض رما يقارب من . . بـامَّ. وسام حميد صباح

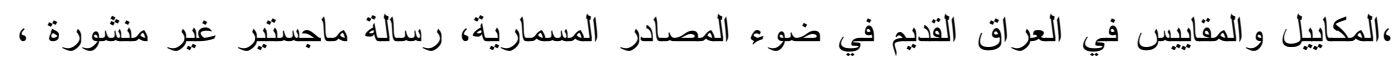

$$
\begin{aligned}
& \text { (موصل :11) }
\end{aligned}
$$

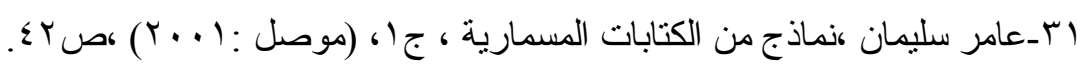

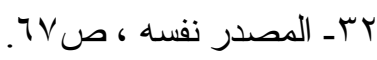

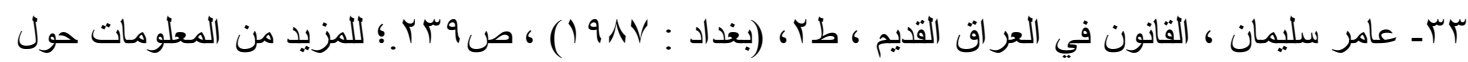

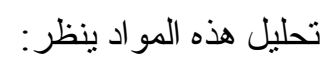

G.R.Driver and John C.Miles, The Babylonian Laws,vol.1, (Oxford:1952), pp.152-153.

ع ז- عامر سليمان ، الحياة الاجتماعية والخدمات في المدن العر اقية ، المدينة و الحياة المدنية ، جا ،(بغداد :

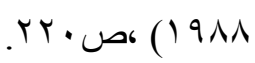

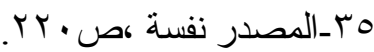

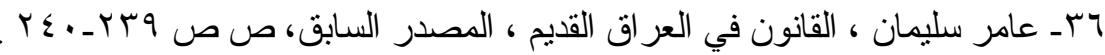

Martha .R. op.cit,p.92.

ibid,p. 92. 
• ع -عُرفت هذه القو انين بالوسيطة كونها تعود بتاريخها إلى العصر الآشوري الوسيط الذي حدده المؤرخون بشكل

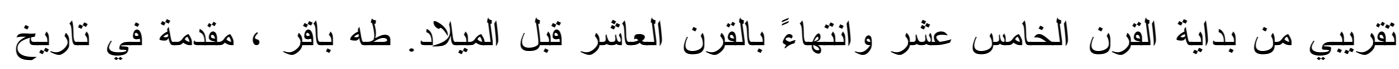

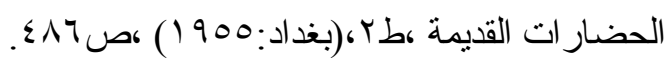

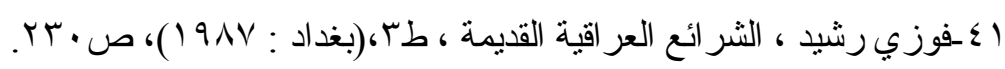

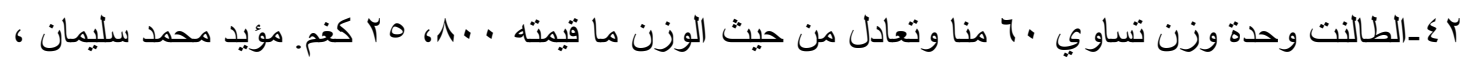

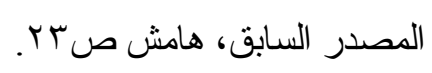

Martha .R, p. 179

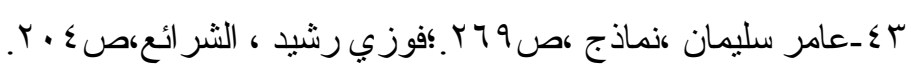

Martha. R,pp.179-180.

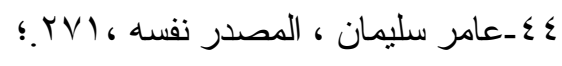

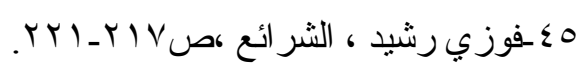

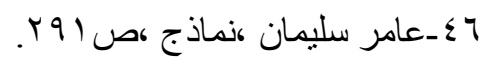

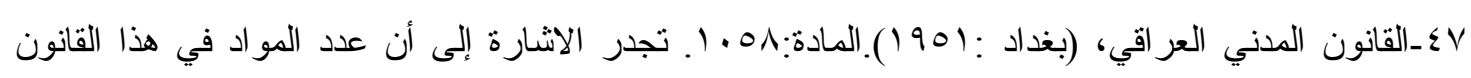

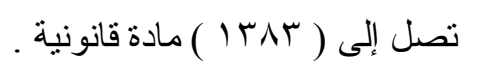

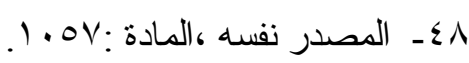

9ء-سمي القانون باسم لبت عشتار نسبة إلى الملك لبت عشتار خامس ملوك سلالة ايسن الذي حكم للمدة

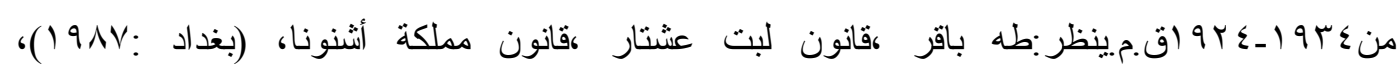

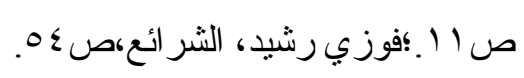

.

10-يعدّ قانون مملكة أثنونا المكتشف في نل حرمل من أقدم القو انين العر اقية القديمة ،و هو يسبق قانون حمور ابي بما يقرب من نصف قرن أو أكثر ،وهو مدون باللغة البابلية وعدد مواده القانونية (آج) مادة. طه باقر

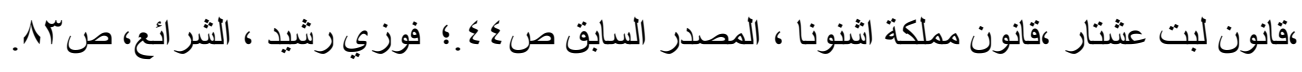

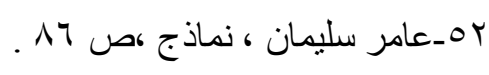
ror

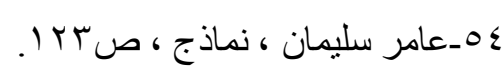

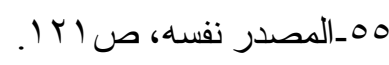

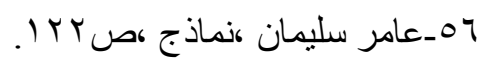


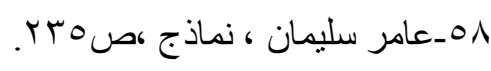

Martha ,p.159

Martha ,p. 160.

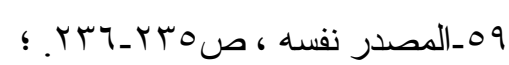

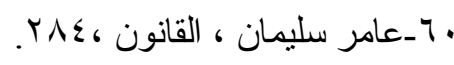

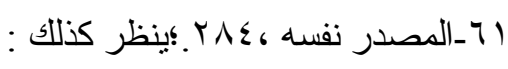

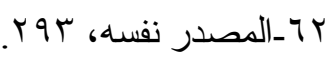

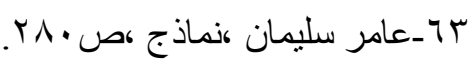

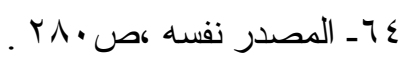

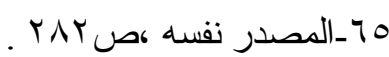




$$
\begin{aligned}
& \text { مصادر البحث }
\end{aligned}
$$

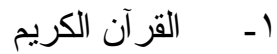

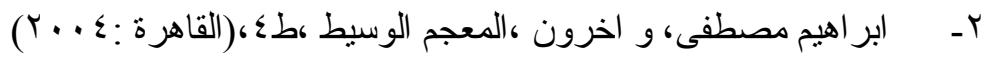

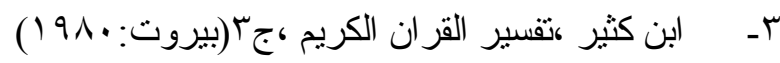

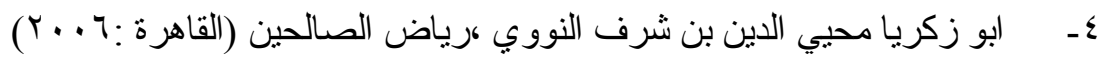

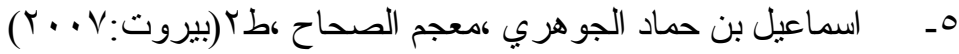

7- أمين عبدالنافع أمين ، صيغ العقود البابلية في النصوص المسمارية ، رسالة ماجسنير غير منشورة

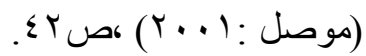

- - مورج بوييه ، المسؤولية الجزائرية في الاداب الاشورية و البابلية كترجمة سليم الصويص

$$
\text { (بغداد: (191) }
$$

^ـ رينة لابات ،قاموس العلامات المسمارية ،ترجمة البير ابونا ،و اخرون ،المجمع العلمي العر اقي

$$
\text { (بغداد: })
$$

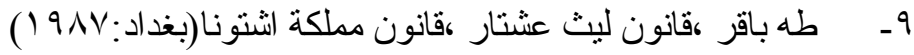
• 1 - طه باقر ،مقدمة في تاريخ الحضار ات القديمة ،طّ،(بغداد : 1900)

11 - عامر سليمان ،الحياة الاجتماعية و الخدمات في المدن العراقية ،المدينة و الحياة المدنية ط

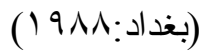

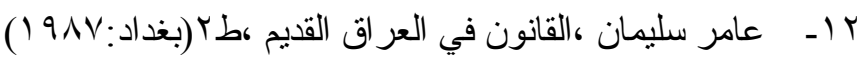

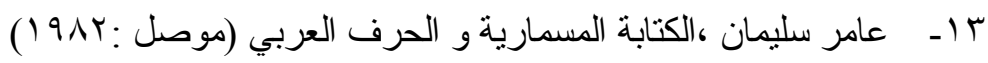

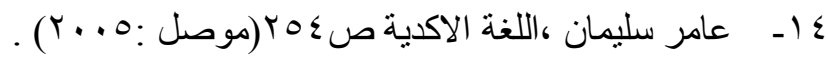

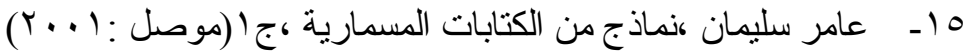

7 ا - عباس العبودي ،شريعة حمور ابي در اسة مقارنة قانونية مقارنة مع التشريعات الحديثة (موصل: •99 (1) )

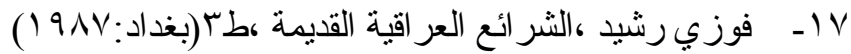
11 1 - ـ القانون المدني العر اقي (بغداد:1901)

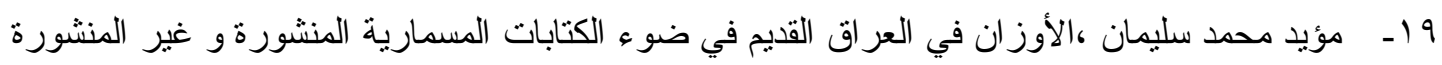

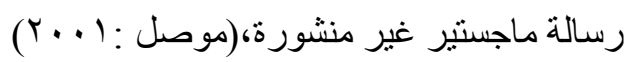

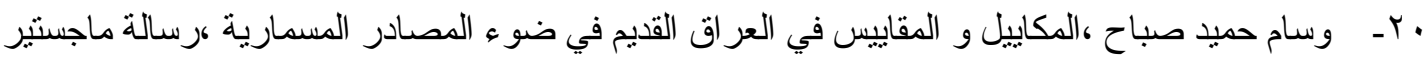

$$
\text { غير منشورة ، (موصل :(Y... (Y) }
$$

21- AHW :Vonsoden, Akkadisches Hand Worte buch (Wiesbaden:1959),p.1383b.

22- CAD,I,T,VOL,7

23- G.R.Driver and Johnc.Miles, The BabyLonian Laws vol.1,(oxford:1956)

24- http://Fathkker,blogspot.com

25- Martha.T.R.law collection from Mesopotamia and Asia minor ,2ed,(atlanta:1997) 




\section{Journal}

\section{AL- Rafedain Archaeology}

Accredited Scientific Journal

It Search's in Archaeology of Iraq and Ancient Near East

Published by College of Archaeology - University of Mosul

E_Mail:ali_aljuboori@yahoo.com 


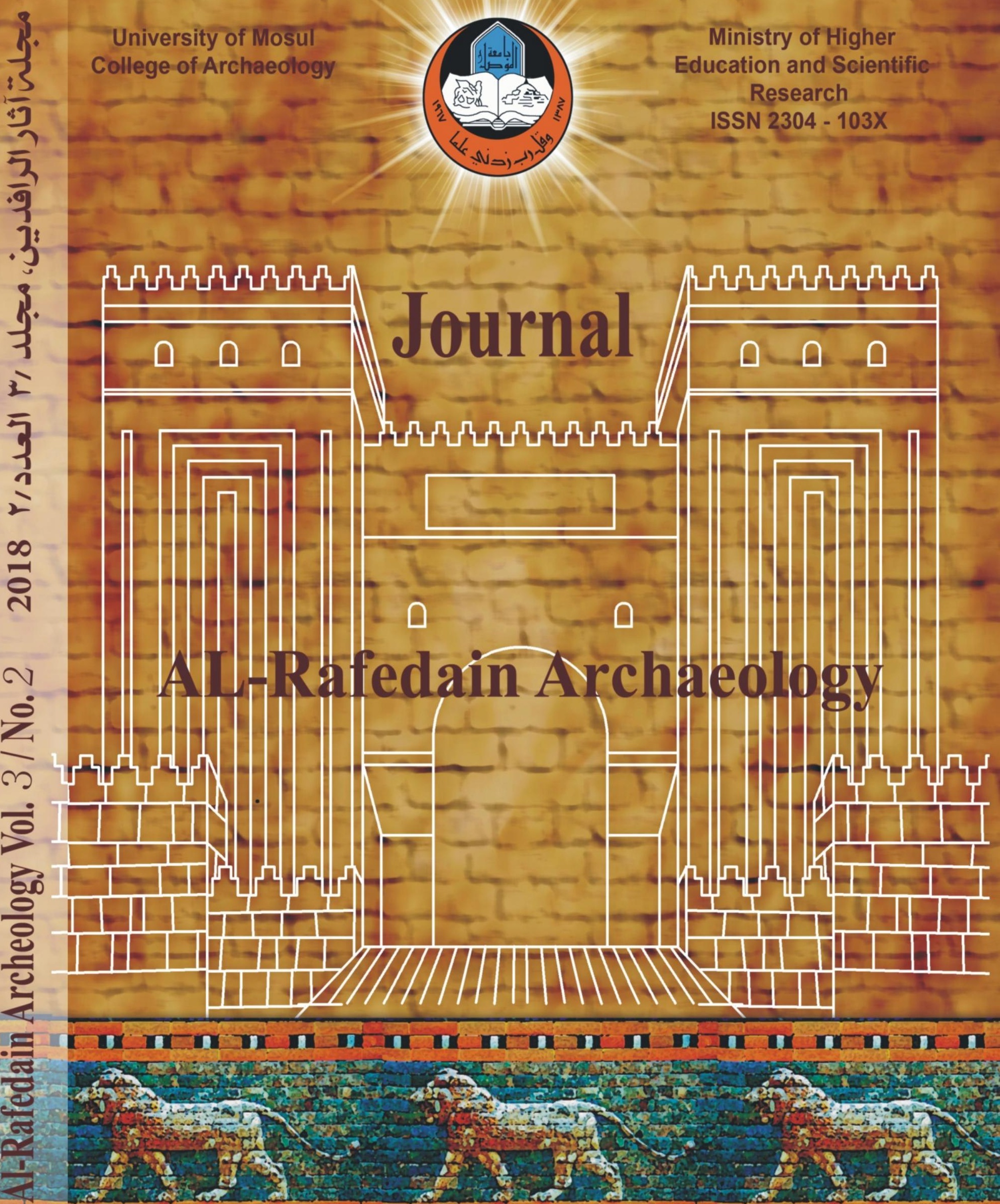

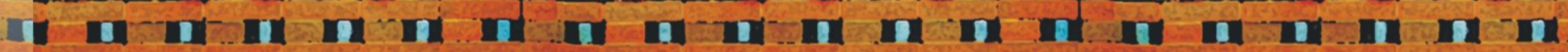

